\title{
Methanogenic archaea use a bacteria-like methyltransferase system to demethoxylate aromatic compounds
}

\author{
Julia M. Kurth ${ }^{1,2}$ - Masaru K. Nobu $\mathbb{1}^{3}$. Hideyuki Tamaki ${ }^{3}$. Nadieh de Jonge ${ }^{4}$ - Stefanie Berger ${ }^{1}$. \\ Mike S. M. Jetten ${ }^{1,2,5} \cdot{\text { Kyosuke Yamamoto } \mathbb{1}^{6} \cdot \text { Daisuke Mayumi }^{7} \cdot \text { Susumu Sakata }}^{7} \cdot$ Liping Bai $^{8} \cdot$ Lei Cheng $^{8}$.

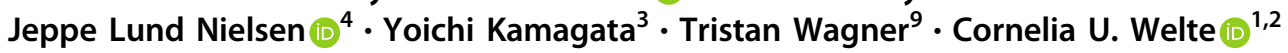

Received: 26 February 2021 / Revised: 11 May 2021 / Accepted: 26 May 2021 / Published online: 18 June 2021

(c) The Author(s) 2021. This article is published with open access

\begin{abstract}
Methane-generating archaea drive the final step in anaerobic organic compound mineralization and dictate the carbon flow of Earth's diverse anoxic ecosystems in the absence of inorganic electron acceptors. Although such Archaea were presumed to be restricted to life on simple compounds like hydrogen $\left(\mathrm{H}_{2}\right)$, acetate or methanol, an archaeon, Methermicoccus shengliensis, was recently found to convert methoxylated aromatic compounds to methane. Methoxylated aromatic compounds are important components of lignin and coal, and are present in most subsurface sediments. Despite the novelty of such a methoxydotrophic archaeon its metabolism has not yet been explored. In this study, transcriptomics and proteomics reveal that under methoxydotrophic growth $M$. shengliensis expresses an $O$-demethylation/methyltransferase system related to the one used by acetogenic bacteria. Enzymatic assays provide evidence for a two step-mechanisms in which the methylgroup from the methoxy compound is (1) transferred on cobalamin and (2) further transferred on the $\mathrm{C}_{1}$-carrier tetrahydromethanopterin, a mechanism distinct from conventional methanogenic methyl-transfer systems which use coenzyme $\mathrm{M}$ as final acceptor. We further hypothesize that this likely leads to an atypical use of the methanogenesis pathway that derives cellular energy from methyl transfer (Mtr) rather than electron transfer $\left(\mathrm{F}_{420} \mathrm{H}_{2}\right.$ re-oxidation) as found for methylotrophic methanogenesis.
\end{abstract}

These authors contributed equally: Julia M. Kurth, Masaru K. Nobu

Supplementary information The online version contains supplementary material available at https://doi.org/10.1038/s41396021-01025-6.

Masaru K. Nobu

m.nobu@aist.go.jp

$\triangle$ Cornelia U. Welte

c.welte@science.ru.nl

1 Department of Microbiology, Institute for Water and Wetland Research, Radboud University, Nijmegen, The Netherlands

2 Soehngen Institute of Anaerobic Microbiology, Radboud University, Nijmegen, The Netherlands

3 Bioproduction Research Institute, National Institute of Advanced Industrial Science and Technology (AIST), Tsukuba, Japan

4 Department of Chemistry and Bioscience, Aalborg University, Aalborg East, Denmark

\section{Introduction}

Methanogenesis evolved more than $3.46 \mathrm{Gyr}$ ago and has profoundly contributed to Earth's climate [1,2]. About 70\% of the emitted methane $\left(\mathrm{CH}_{4}\right)$ is produced by methanegenerating archaea (methanogens; [3]) underlining the importance of methanogenesis for the global carbon cycle.

5 Netherlands Earth System Science Center, Utrecht University, Utrecht, The Netherlands

6 Bioproduction Research Institute, National Institute of Advanced Industrial Science and Technology (AIST), Sapporo, Japan

7 Institute for Geo-Resources and Environment, Geological Survey of Japan, National Institute of Advanced Industrial Science and Technology (AIST), Tsukuba, Japan

8 Key Laboratory of Energy Microbiology and Its Application of Ministry of Agriculture, Biogas Institute of Ministry of Agriculture, Chengdu, China

9 Microbial Metabolism research group, Max Planck Institute for Marine Microbiology, Bremen, Germany 
Methanogens are known to produce methane from one- to two-carbon substrates (i.e., carbon dioxide $\left[\mathrm{CO}_{2}\right]$, acetate, and methylated compounds), often using (in)organic compounds as electron donors (e.g., hydrogen $\left[\mathrm{H}_{2}\right]$ and formate). Three major pathways of methanogenesis are known. In the hydrogenotrophic pathway, $\mathrm{H}_{2}$ (or formate) are used as electron donors with carbon dioxide as electron acceptor. In the methylotrophic pathway, small methylated carbon compounds are converted to methane and carbon dioxide. In the aceticlastic pathway, acetate is cleaved to methane and carbon dioxide [4]. Beyond this, a thermophilic methanogen isolated from a deep subsurface environment [5], Methermicoccus shengliensis, was recently discovered to directly generate methane from a variety of methoxylated aromatic compounds $\left(\mathrm{ArOCH}_{3}\right)$ [6]. Methoxylated aromatic compounds are derived from lignin and occur in large quantities on Earth [7]. The environmental abundance of methoxylated aromatics indicates that methoxydotrophic archaea might play a so far unrecognized and underestimated role in methane formation and carbon cycling of coal, lignin, and other humic substances, especially in the subsurface [8]. Aromatic compounds are a major component of crude oil with about 20-43\% [9, 10], and it is quite likely that methoxylated aromatic compounds in oil might be degraded by methoxydotrophic organisms. As M. shengliensis has been isolated from oil production water [5], the organism might play a role in the degradation of methoxy compounds in oil reservoirs. Next to oil, methoxylated aromatic compounds are components of coal. Although conversion of coal compounds to methane has been thought to require metabolic interactions [11], Methermicoccus' ability to accomplish this alone might have significant implications for coalbed methane formation (7\% of global annual methane formation [12]), including enhanced methane recovery [13]. Therefore, it is important to understand the unique methoxy compound-degrading methane-forming metabolism of $M$. shengliensis.

The discovery of the methoxydotrophic ability of M. shengliensis revealed that the capacity to degrade methoxylated aromatic compounds is not confined to bacteria as previously thought, yet how M. shengliensis (and thus archaea) accomplish methoxydotrophic methanogenesis remains unknown. The organism is also capable of and possesses the necessary genes for methylotrophic methanogenesis [6], in which a methylated substrate (e.g., methanol) is disproportionated to $3 / 4 \mathrm{CH}_{4}$ and $1 / 4 \mathrm{CO}_{2}$. In principle, degradation of methoxy groups could follow a similar pathway, given that methyl and methoxy groups have the same oxidation state. However, isotope-based investigation showed that methoxydotrophic methanogenesis unprecedentedly entails both methyl disproportionation and $\mathrm{CO}_{2}$ reduction to $\mathrm{CH}_{4}$ [6], suggesting the involvement of a novel methanogenic pathway. In this study, integration of genomics, transcriptomics, and proteomics reveals that $M$. shengliensis methoxydotrophy employs a novel methyltransferase system for $\mathrm{ArOCH}_{3} O$-demethylation. While known methanogens transfer methyl compounds using coenzyme $\mathrm{M}(\mathrm{CoM})$ as a $\mathrm{C}_{1}$ carrier [14], we suggest that the M. shengliensis $\mathrm{ArOCH}_{3}$ methyltransferase rather uses tetrahydromethanopterin $\left(\mathrm{H}_{4} \mathrm{MPT}\right)$ as final $\mathrm{C}_{1}$ carrier. The different entry point into methanogenesis (i.e., as $\mathrm{CH}_{3}$ $\mathrm{H}_{4} \mathrm{MPT}$ rather than $\mathrm{CH}_{3}$-CoM) putatively prompts changes in energetics, thermodynamics, and kinetics that might involve an idiosyncratic $\mathrm{C}_{1}$ catabolism cycling between oxidation and reduction.

\section{Materials and methods}

\section{Genome analysis}

The functions of individual proteins were predicted using homology, phylogeny, and domain identification. Homology of $M$. shengliensis proteins with proteins in reference genomes was calculated using NCBI blastp. For each protein, phylogenetic analysis was performed by collecting homologues from the SwissProt and UniProt databases [15], protein sequence alignment using MAFFT v7.394 [16], and phylogenetic tree construction using RAxML-NG v0.5.1b [17] or FastTree v 2.2.11 [18]. Annotations were verified using domain-based function annotation involving NCBI CD-SEARCH/CDD v3.18 (10.1093/nar/gku1221), InterProScan v5 [19], SignalP 4.1 [20], and Prosite (https:// prosite.expasy.org).

\section{Cultivation of Methermicoccus shengliensis}

M. shengliensis AmaM was cultivated as described previously [6]. The following medium was used for the AmaM cultures: a bicarbonate-buffered mineral medium $(\mathrm{pH}$ 7.0) [21] containing $0.15 \mathrm{gl}^{-1} \mathrm{KH}_{2} \mathrm{PO}_{4}, 0.5 \mathrm{gl}^{-1} \mathrm{NH}_{4} \mathrm{Cl}, 0.2 \mathrm{gl}^{-1} \mathrm{MgCl}_{2} \cdot 6 \mathrm{H}_{2} \mathrm{O}$, $0.15 \mathrm{~g} \mathrm{l}^{-1} \mathrm{CaCl}_{2} \cdot 2 \mathrm{H}_{2} \mathrm{Og}, 2.5 \mathrm{~g} \mathrm{l}^{-1} \mathrm{NaHCO}_{3}, 0.3 \mathrm{~g} \mathrm{l}^{-1}$ cysteine. $\mathrm{HCl}, 0.3 \mathrm{gl}^{-1} \mathrm{Na}_{2} \mathrm{~S} \cdot 9 \mathrm{H}_{2} \mathrm{O}, 20.5 \mathrm{~g} \mathrm{l}^{-1} \mathrm{NaCl}, 1 \mathrm{ml}$ trace elements solution (DSMZ medium 318 with slight modifications: $\mathrm{NaCl}$ was eliminated, and $3 \mathrm{mg} \mathrm{l}^{-1}$ of $\mathrm{Na}_{2} \mathrm{WO}_{4} \cdot 2 \mathrm{H}_{2} \mathrm{O}$ and 2 $\mathrm{mg} \mathrm{l}^{-1}$ of $\mathrm{Na}_{2} \mathrm{SeO}_{3}$ were added), $1 \mathrm{ml}$ vitamin solution (DSMZ medium 141 with a slight modification: all components were mixed at a concentration of $\left.20 \mu \mathrm{mol} \mathrm{l}^{-1}\right)$, and $1 \mathrm{ml}$ resazurin solution $\left(1 \mathrm{mg} \mathrm{ml}^{-1}\right)$. As an energy source, cultures were grown with either methanol $(\mathrm{MeOH})(10 \mathrm{mM})$, trimethylamine $(10 \mathrm{mM})$, 2-methoxybenzoate $(10 \mathrm{mM})$, or 3,4,5-trimethoxybenzoate (TMB) $(10 \mathrm{mM})$. A $0.5 \mathrm{M}$ stock solution of TMB was produced by dissolving 3,4,5-trimethoxybenzoic acid in water and adjusting the $\mathrm{pH}$ to 7 with $\mathrm{NaOH}$.

Methermicoccus shengliensis ZC-1 (DSM 18856) was obtained from the DSMZ (Braunschweig, Germany) and 
cultivated in modified DSM medium 1084. Sludge fluid was replaced by trace element solution $(100 \mathrm{x}$ trace element solution: $1.5 \mathrm{~g} \mathrm{l}^{-1}$ nitrilotriacetic acid, $3 \mathrm{~g} \mathrm{l}^{-1} \mathrm{MgSO}_{4} \cdot 7 \mathrm{H}_{2} \mathrm{O}$, $0.45 \mathrm{~g} \mathrm{l}^{-1} \mathrm{MnSO}_{4} \cdot 2 \mathrm{H}_{2} \mathrm{O}, 1 \mathrm{~g} \mathrm{l}^{-1} \mathrm{NaCl}, 0.1 \mathrm{~g} \mathrm{l}^{-1} \mathrm{FeSO}_{4} \cdot 7$ $\mathrm{H}_{2} \mathrm{O}, 0.18 \mathrm{~g} \mathrm{l}^{-1} \mathrm{CoSO}_{4} \cdot 6 \mathrm{H}_{2} \mathrm{O}, 0.1 \mathrm{~g} \mathrm{l}^{-1} \mathrm{CaCl}_{2} \cdot 2 \mathrm{H}_{2} \mathrm{O}, 0.18$ $\mathrm{g} \mathrm{l}^{-1} \mathrm{ZnSO}_{4} \cdot 7 \mathrm{H}_{2} \mathrm{O}, 0.01 \mathrm{~g} \mathrm{l}^{-1} \mathrm{CuSO}_{4} \cdot 5 \mathrm{H}_{2} \mathrm{O}, 0.02 \mathrm{~g} \mathrm{l}^{-1} \mathrm{KAl}$ $\left(\mathrm{SO}_{4}\right)_{2} \cdot 12 \mathrm{H}_{2} \mathrm{O}, \quad 0.01 \mathrm{~g} \mathrm{l}^{-1} \mathrm{H}_{3} \mathrm{BO}_{3}, 0.01 \mathrm{~g} \mathrm{l}^{-1} \quad \mathrm{Na}_{2} \mathrm{WO}_{4} \cdot 2$ $\mathrm{H}_{2} \mathrm{O}, 0.01 \mathrm{~g} \mathrm{l}^{-1} \mathrm{Na}_{2} \mathrm{MoO}_{4} \cdot 2 \mathrm{H}_{2} \mathrm{O}, 0.025 \mathrm{~g} \mathrm{l}^{-1} \mathrm{NiCl}_{2} \cdot 6 \mathrm{H}_{2} \mathrm{O}$, $0.01 \mathrm{~g}^{-1} \mathrm{Na}_{2} \mathrm{SeO}_{3}$ ) and vitamin solution (1000 x vitamin solution: $20 \mathrm{mg} \mathrm{l}^{-1}$ biotin, $20 \mathrm{mg} \mathrm{l}^{-1}$ folic acid, $100 \mathrm{mg} \mathrm{l}^{-1}$ pyridoxine- $\mathrm{HCl}, 50 \mathrm{mg} \mathrm{l}^{-1}$ thiamin- $\mathrm{HCl} \cdot 2 \mathrm{H}_{2} \mathrm{O}, 50 \mathrm{mg} \mathrm{l}^{-1}$ riboflavin, $50 \mathrm{mg} \mathrm{l}^{-1}$ nicotinic acid, $50 \mathrm{mg} \mathrm{l}^{-1}$ D-Ca-pantothenate, $2 \mathrm{mg} \mathrm{l}^{-1}$ vitamin $\mathrm{B}_{12}, 50 \mathrm{mg} \mathrm{l}^{-1} \mathrm{p}$-aminobenzoic acid, $50 \mathrm{mg}^{-1}$ lipoic acid). The amount of supplied coenzyme $\mathrm{M}$ was reduced 20-fold $\left(0.13 \mathrm{gl}^{-1}\right)$ and $2.5 \mathrm{~g} \mathrm{l}^{-1}$ $\mathrm{NaHCO}_{3}$ instead of $1 \mathrm{~g} \mathrm{l}^{-1} \mathrm{Na}_{2} \mathrm{CO}_{3}$ was used. The medium was sparged with $\mathrm{N}_{2}: \mathrm{CO}_{2}$ in a $80: 20$ ratio before autoclaving. As substrate either $150 \mathrm{mM} \mathrm{MeOH}$ or $10 \mathrm{mM}$ TMB were used. The cultures were incubated at $65^{\circ} \mathrm{C}$. Identity of the organism was checked by $16 \mathrm{~S}$ rRNA gene sequencing of DNA from TMB grown cell with primers Arch349F (5'GYGCAGCAGGCGCGAAA-3') and Arch806R (5'-GGAC TACVSGGGTATCTAAT-3') [22].

\section{RNA isolation from $M$. shengliensis cells and sequencing}

For transcriptomics, M. shengliensis AmaM was cultivated in 130-ml serum vials containing $50 \mathrm{ml}$ of the medium with $10 \mathrm{mM} \mathrm{MeOH}$, 2-methoxybenzoate, trimethylamine, or TMB as the sole organic carbon substrate. Total RNA was extracted from the cells harvested in the exponential growth phase through brief centrifugation $(3 \mathrm{~min}$ at $9000 \times g$ at room temperature) using methods described by Schmidt et al. [23] with slight modifications. In brief, after adding extraction buffer $(0.1 \mathrm{M}$ Tris- $\mathrm{HCl}, 0.1 \mathrm{M}$ ethylenediaminetetraacetic acid, $0.75 \mathrm{M}$ sucrose), cells were enzymatically and chemically lysed by lysozyme $\left(1 \mathrm{mg} \mathrm{ml}^{-1}\right)$, achromopeptidase $\left(0.01 \mathrm{mg} \mathrm{ml}^{-1}\right)$, proteinase $\mathrm{K}\left(0.1 \mathrm{mg} \mathrm{ml}^{-1}\right)$, and sodium dodecyl sulfate $(1 \%[\mathrm{w} / \mathrm{v}])$. The nucleic acid fraction was extracted using cetyl trimethyl ammonium bromide (1\% [w/v]) and chloroform-isoamyl alcohol (24:1). Extracted nucleic acids were precipitated with isopropanol and washed with ethanol, and then fractionated into DNA and RNA by ALLPrep DNA/RNA mini kit (Qiagen, Hilden, Germany), according to manufacturer's instructions. RNA samples were treated with DNase to remove DNA contaminants. Removal of DNA contamination from the samples was confirmed by PCR amplification. RNA concentrations were measured using a Nanodrop 2000c and Qubit Fluorometer using Qubit RNA HS (Thermo Fisher Scientific, Wilmington, DE, USA).
The resulting cDNA was fragmented using Bioruptor (Diagenode, Inc., Denville, NJ USA), profiled using Agilent Tapestation, and subjected to Beckman Biomek FXp (Biomek 6000, Beckman Coulter) fully automatic workstation and a Beckman HT library kit (SPRIworks HT, Beckman Coulter, Inc. CA USA; PN B09855AA) to generate fragment libraries. The instructions were strictly followed to perform library construction. Briefly, after fragmentation the ends were repaired and the fragments were subsequently adenylated. Adapters were then ligated to both ends. The adaptor-ligated templates were further purified using Agencourt AMPure SPRI beads (Beckman Coulter, Inc. CA USA). The adaptor-ligated library was amplified by ligation-mediated PCR which consisted of 11 cycles of amplification, and the PCR product was purified using Agencourt AMPure SPRI beads again. After the library construction procedure was completed, QC was performed using Nanodrop 2000 (Thermo Scientific, USA) and an Agilent TapeStation (Agilent, USA) to ensure the library quality and quantity. Alternatively, cDNA was profiled using Agilent Bioanalyzer, and subjected to library preparation using NEBNext reagents (New England Biolabs, Ipswich, MA USA, catalog\# E6040). The quality and quantity and size distribution of the libraries were determined using an Agilent Bioanalyzer 2100.

Sequencing was performed on the HiSeq 2500 (Rapid run, Illumina, CA USA) with chemistry v3.0 and using the $2 \times 100$ bp paired-end read mode and original chemistry from Illumina according to the manufacturer's instructions. The initial data analysis was started directly on the HiSeq 2500 System during the run. The HiSeq Control Software 2.0.5 in combination with RTA 1.17.20.0 (real-time analysis) performed the initial image analysis and base calling. In addition, CASAVA-1.8.2 generated and reported run statistics and the final FASTQ files comprising the sequence information which was used for all subsequent bioinformatics analyses. Sequences were de-multiplexed according to the $6 \mathrm{bp}$ index code with 1 mismatch allowed. Alternatively, the libraries were then submitted for Illumina HiSeq2000 sequencing according to the standard operation. Paired-end 90 or 100 nucleotide (nt) reads were generated, checked for data quality using FASTQC (Babraham Institute, Cambridge, UK).

For $M$. shengliensis ZC-1, cells were harvested in the exponential phase $\left(\mathrm{MeOH}\right.$ grown cells: $\mathrm{OD}_{600} 0.150$ to 0.240 and $\mathrm{TMB}$ grown cells: $\mathrm{OD}_{600} 0.110$ to 0.180 ) at $10,000 \times g, 25 \mathrm{~min}$ and $4{ }^{\circ} \mathrm{C}$. The pellet was frozen in liquid nitrogen and stored at $-80^{\circ} \mathrm{C}$ until RNA isolation. RNA isolation was performed with the RiboPure-Bacteria Kit (Thermo Fischer Scientific) according to manufacturer's instructions. Quantity and quality of RNA from $\mathrm{MeOH}$ and TMB grown cells (in triplicates) was checked with an 
Agilent 2100 Bioanalyzer and the RNA Integrity Number was between 7.2 and 8.2.

For library preparation the TruSeq Stranded mRNA Library Prep protocol (Illumina, San Diego, California USA) was used according to the manufacturer's instructions. Total RNA was used for library preparation. The library concentration measured with a Qubit fluorometer and the average fragment size obtained with the Agilent 2100 Bioanalyzer were used to calculate the correct dilution factor required for normalization of the library. After dilution to $4 \mathrm{nM}$ and denaturation using the Denature and Dilute Libraries Guide (Illumina, San Diego, CA), the library was sequenced using a MiSeq machine (Illumina, San Diego, $\mathrm{CA})$ to generate $150 \mathrm{bp}$ single-end reads.

To analyze the AmaM and ZC- 1 transcriptomic data, raw reads from the MiSeq platform were trimmed using Trimmomatic v0.36 (SLIDINGWINDOW:6:30 MINLEN:50 LEADING:3 TRAILING:3) [24] and mapped to the respective genomes (AmaM - JGI IMG/M ID 2516653088; ZC-1 - GenBank accession number NZ_JONQ00000000.1) using BBMap v38.26 $($ semiperfectmode $=\mathrm{t})($ https://jgi.doe . gov/data-and-tools/bbtools/).

\section{Analysis of $M$. shengliensis ZC-1 whole cell proteome}

After cultivation of $M$. shengliensis in medium with either $\mathrm{MeOH}$ or TMB as substrate cells were harvested anaerobically $(13,000 \times g, 25 \mathrm{~min})$ in the exponential phase $\left(\mathrm{OD}_{600 \mathrm{~nm}} 0.2-0.4\right)$, pellets were frozen in liquid nitrogen and freeze-dried before they were stored at $-80^{\circ} \mathrm{C}$ in quadruplicates.

After adding $400 \mu \mathrm{L}$ ammonium bicarbonate $(100 \mathrm{mM}$, $\mathrm{pH} 8$ ) and resuspending, the samples were transferred together with $300 \mu \mathrm{L}$ TEAB resuspension buffer $(50 \mathrm{mM}$ triethylammonium bicarbonate, $1 \%(\mathrm{w} / \mathrm{w})$ sodium deoxycholate, $\mathrm{pH}$ 8.0) and $300 \mu \mathrm{L}$ B-PER reagent (Thermo Fisher) to $200 \mathrm{mg}$ glass beads in shock resistant $2 \mathrm{~mL}$ tubes. Bead beating was performed using Precellys 24 (Bertin Technologies, France) at $6000 \mathrm{rpm}$ for $20 \mathrm{~s}$ with a $30 \mathrm{~s}$ break for three cycles. After centrifugation at $14,000 \times g$ for $10 \mathrm{~min}$ at $4{ }^{\circ} \mathrm{C}$, supernatant was transferred to a $1.5 \mathrm{~mL}$ Eppendorf tube.

To precipitate the proteins one volume $100 \%$ TCA was added to four volumes of protein extract. After incubation at $4{ }^{\circ} \mathrm{C}$ for $10 \mathrm{~min}$, the supernatant was removed and the pellet washed two times with $200 \mu \mathrm{L}$ ice cold acetone (centrifugation at $14,000 \times g$ for $5 \mathrm{~min}$ at $4{ }^{\circ} \mathrm{C}$ ). The pellet was dried at $95^{\circ} \mathrm{C}$ for $5 \mathrm{~min}$ and resuspended in $50 \mu \mathrm{L}$ ammonium bicarbonate $(100 \mathrm{mM}, \mathrm{pH} 8)$. Protein concentration was estimated using Qubit Protein Assay Kit (Thermo Fisher Scientific) and a Qubit 3.0 fluorometer (Thermo Fisher Scientific).
In solution digestion was performed by adding one volume TEAB resuspension buffer to the protein extracts followed by incubation at $99{ }^{\circ} \mathrm{C}$ for $5 \mathrm{~min}$. Subsequently, samples were reduced using $1 \mu \mathrm{g}$ TCEP per $25 \mu \mathrm{g}$ protein and incubation at $37{ }^{\circ} \mathrm{C}$ for $30 \mathrm{~min}$, and alkylated with $1 \mu \mathrm{g}$ Iodoacetamide per $10 \mu \mathrm{g}$ protein followed by incubation at $37{ }^{\circ} \mathrm{C}$ for $20 \mathrm{~min}$ in the dark. Digestion was performed using $1 \mu \mathrm{g}$ trypsin per $50 \mu \mathrm{g}$ protein and incubation at $37^{\circ} \mathrm{C}$ for $16 \mathrm{~h}$. A final concentration of $2 \%$ formic acid was added to the samples and after $5 \mathrm{~min}$ incubation at room temperature, the samples were centrifuged at $13,000 \times g$ for 20 min at $4{ }^{\circ} \mathrm{C}$. The supernatant was transferred into a new tube.

Samples were desalted using a modified StageTIP protocol [25] and subsequently lyophilised in a SpeedVac centrifuge. Peptides were reconstituted in $2 \%(\mathrm{v} / \mathrm{v})$ acetonitrile and $0.1 \%$ formic acid prior to analysis.

LC-MS/MS analysis of the samples was performed using an Easy-nLC 1200 system (Thermo Scientific) coupled to a Q Exactive HF mass spectrometer (Thermo Scientific) through a Nanospray Flex ion source (Thermo Scientific). Peptides were loaded onto an Acclaim PepMap 100 $(100 \mu \mathrm{m} \times 2 \mathrm{~cm}$, NanoViper, C18, $5 \mu \mathrm{m}, 100 \mathrm{~A})$ (Thermo Scientific) trap column and separated on an analytical column at a flow rate of $300 \mathrm{~nL} \mathrm{~min}{ }^{-1}$, during a 40 min linear gradient, ranging from 0 to $100 \%$ of a mobile phase containing acetonitrile.

Mass spectrometry was performed in positive mode only, fragmenting precursors with an assigned charge of $\geq 2$. An isolation window of $1.2 \mathrm{~m} / z$ was used and survey scans were acquired at $400-1200 \mathrm{~m} / \mathrm{z}$ at resolution 60,000 at $\mathrm{m} / \mathrm{z}$ 200 , and fragmentation spectra were captured at 15,000 at $\mathrm{m} / \mathrm{z}$ 200. Maximum ion injection time was set to $50 \mathrm{~ms}$ for MS and $45 \mathrm{~ms}$ for MS/MS scans. Automatic gain for survey scans was set to $1 \mathrm{e} 6$ ions and 1e5 ions for fragmentation scans. The apex trigger was not set, the intensity threshold was set to $4.4 \mathrm{e} 4$ ions and dynamic exclusion of $30 \mathrm{~s}$ was applied. Normalized Collision Energy was set to 28, "peptide match" was set to "preferred" and "exclude isotopes" was enabled.

Q-exactive RAW data files were processed using MaxQuant (v1.6.3.4) [26], with carbamidomethylation set as a fixed modification and methionine oxidation as a variable modification, a protein, and peptide false discovery rate (FDR) of $1 \%$ and label-free quantification (LFQ) as implemented in MaxQuant. Data were searched against a database consisting of the predicted open reading frames (ORFs) of the draft genome of M. shengliensis ZC-1 (NZ_JONQ00000000.1), as well as the ORFs of closely related organisms Methanothrix thermoacetophila (UP000000674), Methanothrix harundinacea (UP000005877), Methanosarcina barkeri (UP000033066), Methanolacinia petrolearia (UP000006565) and 
Methanomethylovorans hollandica (UP000010866), downloaded from UniProt on 18-01-2019.

Data analysis was performed using Perseus (v1.6.2.3) [27]. Student's $t$ test was performed using a significance level of $p \leq 0.05$ and permutation-based FDR at $5 \%$. The relative protein abundances were represented as Log2transformed LFQ values. Fold change was expressed as the ratio of averaged LFQ value of a protein across all replications of M. shengliensis fed with TMB divided by the averaged LFQ value of those fed with methanol.

\section{Native purification of MtoA and MtoB from $M$. shengliensis}

All steps were performed under an anaerobic atmosphere and all buffers were prepared anaerobically. About $6 \mathrm{~g}$ (wet weight) of $M$. shengliensis $\mathrm{ZC}-1$ cells harvested in the late exponential phase were defrosted while gassing for $10 \mathrm{~min}$ with $\mathrm{N}_{2}$ gas and passed in an anaerobic tent containing an atmosphere of $\mathrm{N}_{2} / \mathrm{CO}_{2}$ at a ratio of 90:10\%. Afterwards, cells were resuspended in $20 \mathrm{~mL}$ anaerobic IECA buffer (50 mM Tris/HCl pH 8, $2 \mathrm{mM}$ dithiothreitol abbreviated as DTT), sonicated (Bandelin sonopuls $6 \times 50 \%$ power for 10 $\mathrm{s}$ with $20 \mathrm{~s}$ break) and centrifuged $(13,000 \times \mathrm{g}, 30 \mathrm{~min}$ at room temperature) to remove cell debris. The supernatant was collected and the pellets were resuspended in $10 \mathrm{ml}$ anaerobic IECA buffer, sonicated $(5 \times 50 \%$ power for $10 \mathrm{~s}$ with $20 \mathrm{~s}$ break), centrifuged $(13,000 \times g, 30 \mathrm{~min})$ and the supernatant combined with the supernatant from the previous step. The supernatant was anaerobically transferred to a Coy tent containing a gas atmosphere of $\mathrm{N}_{2} / \mathrm{H}_{2}$ at a ratio of $97: 3 \%$ and was then diluted fourfold with IECA buffer, filtered through $0.2 \mu \mathrm{m}$ filters (Sartorius), and loaded on a $20 \mathrm{ml}$ DEAE FF column equilibrated with IECA buffer (GE healthcare). Proteins were eluted by applying a 0 to $40 \%$ gradient of $1 \mathrm{M} \mathrm{NaCl}$ by using IECB buffer $(50 \mathrm{mM}$ Tris/ $\mathrm{HCl} \mathrm{pH} 8,2 \mathrm{mM}$ DTT, $1 \mathrm{M} \mathrm{NaCl}$ ), over $150 \mathrm{~min}$ at a flow rate of $2 \mathrm{ml} / \mathrm{min}$ collecting $4 \mathrm{ml}$ fractions. MtoA and MtoB containing fractions were pooled based on sodium dodecyl sulfate-polyacrylamide gel electrophoresis (SDS PAGE) profile. MtoA eluted between 130 and $171 \mathrm{mM} \mathrm{NaCl}$ and MtoB between 171 and $200 \mathrm{mM} \mathrm{NaCl}$. Those two pools were diluted 4-fold with HICB $(25 \mathrm{mM}$ Tris/ $\mathrm{HCl} \mathrm{pH} \mathrm{7.6,}$ $2 \mathrm{mM}$ DTT, and $\left.2 \mathrm{M}\left(\mathrm{NH}_{4}\right)_{2} \mathrm{SO}_{4}\right)$, filtered through $0.2 \mu \mathrm{m}$ filters, and loaded on a $5 \mathrm{ml}$ Phenyl sepharose HP column, separately (GE healthcare). Proteins were eluted by applying a 60 to $0 \%$ gradient of $2 \mathrm{M}\left(\mathrm{NH}_{4}\right)_{2} \mathrm{SO}_{4}$ by using HICA buffer (HICA: $25 \mathrm{mM}$ Tris/HCl pH 7.6, 2 mM DTT) over $60 \mathrm{~min}$ at a flow of $1 \mathrm{ml} / \mathrm{min}$ collecting $2 \mathrm{ml}$ fractions. MtoA eluted in the range of 1.13 and $0.74 \mathrm{M}\left(\mathrm{NH}_{4}\right)_{2} \mathrm{SO}_{4}$ and MtoB eluted in the range of 0.45 and $0.10 \mathrm{M}\left(\mathrm{NH}_{4}\right)_{2} \mathrm{SO}_{4}$. Pooled fractions were diluted 4-fold with HICB, filtered through $0.2 \mu \mathrm{m}$ filters, and loaded on a Source 15 Phe 4.6/
100 PE column (GE healthcare), separately. Proteins were eluted by applying a 70 to $0 \%$ gradient of $2 \mathrm{M}\left(\mathrm{NH}_{4}\right)_{2} \mathrm{SO}_{4}$ by using HICA buffer over $60 \mathrm{~min}$ with a flow rate of $1 \mathrm{ml} /$ min collecting $2 \mathrm{ml}$ fractions. Under these conditions MtoA eluted in the range of 1.44 and $1.18 \mathrm{M}\left(\mathrm{NH}_{4}\right)_{2} \mathrm{SO}_{4}$ and MtoB eluted in the range of 1.27 and $1.09 \mathrm{M}\left(\mathrm{NH}_{4}\right)_{2} \mathrm{SO}_{4}$. Buffer was exchanged to storage buffer $(25 \mathrm{mM}$ Tris/ $\mathrm{HCl}$ $\mathrm{pH} 7.6,10 \% \mathrm{v} / \mathrm{v}$ glycerol, and $2 \mathrm{mM}$ DTT) by a $100-$ fold dilution using a $15 \mathrm{ml}$ Millipore Ultra-10 centrifugal filter units (Merck; $10 \mathrm{kDa}$ cut-off). Protein concentration was measured by Bradford Protein Assay (Bio-Rad) according to the manufacturer's instructions.

MtoA and MtoB were identified with help of matrixassisted laser desorption/ionization time-of-flight mass spectrometry (MALDI-TOF MS) which was performed as explained in the following. Protein bands were cut into small pieces (about $3 \times 3 \mathrm{~mm}$ ) and transferred into an Eppendorf tube. For destaining of the gel pieces, the following solvents/buffers were added successively: $20 \mu \mathrm{l}$ acetonitrile, $20 \mu \mathrm{l} 50 \mathrm{mM}$ ammonium bicarbonate (ABC) buffer, $50 \%$ acetonitrile in $\mathrm{ABC}$ buffer and $20 \mu \mathrm{l}$ acetonitrile. After each addition, samples were swirled and incubated for $10 \mathrm{~min}$ at room temperature followed by removing the liquid from the sample. Those steps were repeated, starting from the addition of $\mathrm{ABC}$ buffer, until the gel pieces were completely destained. For reduction and alkylation, samples were incubated in $20 \mu \mathrm{l} 10 \mathrm{mM}$ dithiothreitol at $56^{\circ} \mathrm{C}$ for $30 \mathrm{~min}$ and after removing the liquid from the samples the following solvents/buffers were added successively: $20 \mu \mathrm{l}$ acetonitrile, $20 \mu \mathrm{l} 50 \mathrm{mM}$ 2-chloroacetamide in $50 \mathrm{mM}$ ABC buffer, $20 \mu \mathrm{l}$ acetonitrile, $20 \mu \mathrm{l} \mathrm{ABC}$ buffer, $20 \mu \mathrm{l}$ acetonitrile and $20 \mu \mathrm{l} \mathrm{ABC}$ buffer. After each addition, samples were swirled and incubated for $10 \mathrm{~min}$ at room temperature followed by removing the liquid from the sample. For trypsin digestion, $10 \mu \mathrm{l}$ of $5 \mathrm{ng} / \mu \mathrm{l}$ trypsin in $\mathrm{ABC}$ buffer were added to the gel pieces followed by 30 min incubation at room temperature. Afterwards $20 \mu \mathrm{ABC}$ buffer were added and the samples were incubated overnight at $37^{\circ} \mathrm{C}$. The samples were sonicated for $20 \mathrm{~s}$ in a Branson 2510 sonication bath (Branson, U.S.). Twenty microliters of $0.1 \%$ trifluoroacetic acid were added. The samples were swirled and incubated for $20 \mathrm{~min}$ at room temperature before the extract liquid was transferred to a new tube. Twenty microliters of acetonitrile were added to the remaining trypsin digest, the samples were swirled and incubated for $30 \mathrm{~min}$ at room temperature before the extract liquid was combined with the extract liquid from before. The samples were then dried in a Sanvant ISS110 speedVac (Thermo Scientific) until $\sim 5 \mu \mathrm{l}$ remain. $0.5 \mu \mathrm{l}$ of the extracted peptides was pipetted on a MALDI-TOF sample plate and directly mixed with an equal volume of matrix solution containing $10 \mathrm{mg} / \mathrm{ml} \alpha$-cyano-4-hydroxy- $\alpha$-cyanocinnamic acid in $50 \%$ acetonitrile/ $0.05 \%$ trifluoroacetic 
acid. After drying of the sample this process was repeated once more. A spectrum in the range of $600-3000 \mathrm{~m} / \mathrm{z}$ was recorded using a Microflex LRF MALDI-TOF (Bruker). The Biotools software (Bruker Life Sciences) was used to perform a MASCOT search (Matrix Science Ltd, London, UK) by using the $M$. shengliensis protein database (GenBank accession number NZ_JONQ00000000.1). Search parameters allowed a mass deviation of $0.3 \mathrm{Da}$, one miscleavage, a variable modification of oxidized methionines and a fixed modification of carbamidomethylated cysteines. For MtoA the molecular weight search (MOWSE) score was 115 and the coverage $41 \%$ and for MtoB the MOWSE score was 70 and the coverage $34 \%$.

\section{Heterologous protein production of MtoC and MtoD}

The gene encoding the corrinoid protein MtoC (BP07_RS03260) and the corrinoid activating enzyme (BP07_RS03235) were amplified from genomic M. shengliensis DNA with primers 3235fw/3235Srev (CTCATAT GAGCGTCAGAGTAACGTTCGAGC, CTGCGGCCGC TTATTTTTCGAACTGCGGGTGGCTCCAGCTAGCTG AAGAGAGTTTTTCTCC) and 3260fw/3260Srev (CTCA TATGACGGACGTAAGAGAAGAGCTC/CTGCGGCC GCTTATTTTTCGAACTGCGGGTGGCTCCAGCTAGC CTCCACCCCCACCAGAGC) for cloning in expression vector $\mathrm{pET}$-30a inserting an N-terminal Strep tag via the reverse primer. For cloning of the above mentioned genes into pET-30a (Novagen), primers included NdeI and NotI restriction sites to insert the digested PCR products into the plasmid. PCR was performed with Phusion polymerase (NEB) according to manufacturer's instructions. For restriction, digest fast digest enzymes (Thermo) were used and for ligation T4-DNA ligase (Promega). E. coli DH5 $\alpha$ (NEB) was used for plasmid transformation.

For production of the corrinoid protein MtoC (BP07_RS03260) and the corrinoid activating enzyme (BP07_RS03235) the plasmids pET-30a_BP07_RS03260 and pET-30a_BP07_RS03235 were used for transformation into $E$. coli B121 (DE3). For protein overexpression, one colony was inoculated in $600 \mathrm{ml} \mathrm{LB}$-medium containing $50 \mu \mathrm{g} / \mathrm{ml}$ kanamycin and incubated at $37^{\circ} \mathrm{C}$ and $180 \mathrm{rpm}$ for $16 \mathrm{~h}$. Cells were harvested by centrifugation $(15,000 \times g$ for $10 \mathrm{~min}$ at $4{ }^{\circ} \mathrm{C}$ ). All further steps were performed anaerobically in an anaerobic hood with anoxic buffers and solutions. Pelleted cells were resuspended in $100 \mathrm{mM}$ Tris$\mathrm{HCl}$ buffer $\mathrm{pH} 8$ containing $150 \mathrm{mM} \mathrm{NaCl}$ and lysed by sonication ( $1 \mathrm{~s}$ pulse, $5 \mathrm{~s}$ pause, $40 \%$ amplitude; $5 \mathrm{~min}$ ). After removal of insoluble cell material by centrifugation $\left(20,000 \times \mathrm{g}\right.$ for $25 \mathrm{~min}$ at $\left.4{ }^{\circ} \mathrm{C}\right)$ proteins were purified by Strep-Tactin XT high capacity affinity chromatography according to the manufacturer's instructions (IBA, Göttingen, Germany). For assessment of purity, sodium dodecyl sulfate-poly-acrylamide gel electrophoresis (SDS-PAGE) was performed.

The protocol for reconstitution of MtoC with cobalamin was adapted from Schilhabel et al. [28]. $1.5 \mathrm{ml}$ (40 mg) anaerobic protein solution was added to $65 \mathrm{ml}$ refolding solution and $650 \mu \mathrm{l} 1 \mathrm{M}$ DTT in a $120 \mathrm{ml}$ glass bottle with a stirrer bar, closed with a rubber stopper (all solutions were made anaerobic by sparging $10 \mathrm{~min}$ with nitrogen gas). The refolding solution contained $50 \mathrm{mM}$ Tris, $3.5 \mathrm{M}$ betaine $\mathrm{HCl}$ and $1 \mathrm{mM}$ hydroxocobalamin $\mathrm{HCl}$, and $\mathrm{pH}$ was adjusted to 7.5. The protein solution then was incubated for $16 \mathrm{~h}$ at $4{ }^{\circ} \mathrm{C}$ in the dark during slight stirring. Afterwards the buffer was exchanged by Tris $\mathrm{HCl} \mathrm{pH} 7.5$ and $1 \mathrm{mM}$ DTT by use of $5 \mathrm{kDa}$ concentration units (Amicon Ultra-15 Centrifugal Filter Units, Merck) several times, until the cobalt containing permeate appeared visibly clear instead of red. Protein was stored anaerobically in $2 \mathrm{ml}$ glass vials closed with air-tight rubber stoppers.

\section{Enzyme activity assays}

Enzyme activity assays were performed in anaerobic $400 \mu \mathrm{l}$ Quartz cuvettes (number 115-10-40, Hellma) which were closed with a rubber stopper and gassed with $\mathrm{N}_{2}$. Cuvettes were heated up to $60{ }^{\circ} \mathrm{C}$ before starting the measurements. All measurements were at least performed in triplicates. Anoxic buffers and solutions were added with gas-tight glass syringes (Hamilton, Reno, NE). MtoB activity was determined in a total volume of $300 \mu \mathrm{l}$ containing a $35 \mathrm{mM}$ Tris $\mathrm{HCl}, 70 \mathrm{mM}$ $\mathrm{KCl}, \mathrm{pH} 7.5$ buffer. Firstly, reconstituted Co(II)-MtoC at 1.2 $\mathrm{mg} / \mathrm{ml}$ final concentration (about $55 \mu \mathrm{M}$ ) was activated by adding $12 \mathrm{mM} \mathrm{MgCl}_{2}, 0.5 \mathrm{mM} \mathrm{Ti}(\mathrm{III})$ citrate (freshly prepared), $2.3 \mathrm{mM}$ ATP and $0.08 \mathrm{mg} / \mathrm{ml}$ MtoD. The conversion to $\mathrm{Co}$ (I)-MtoC was followed by the change in absorbance at $387 \mathrm{~nm}$ on a Cary $60 \mathrm{UV}-\mathrm{Vis}$ spectrophotometer (Agilent Technologies, USA) $\left(\Delta \varepsilon_{386}=21 \mathrm{mM}^{-1} \mathrm{~cm}^{-1}\right.$ [29] was used for our calculations). The reaction was started by the addition of $2.3 \mathrm{mM}$ 2-methoxybenzoate or TMB and MtoB at a final concentration of $0.015 \mathrm{mg} / \mathrm{ml}$. Fifty microliters of sample were removed before addition of MtoB and after the activity assay for analysis of methoxy compounds by HPLC (see below). Formation of $\mathrm{CH}_{3}-\mathrm{Co}$ (III)-MtoC from $\mathrm{Co}$ (I)-MtoC results in a decrease in absorption at $387 \mathrm{~nm}$ which was followed with a Cary $60 \mathrm{UV}-\mathrm{Vis}$ spectrophotometer (Agilent Technologies, USA). Activity was at least measured in triplicates per substrate. As negative control $2.3 \mathrm{mM}$ methanol or trimethylamine were used.

MtoA activity was determined in a total volume of $300 \mu \mathrm{l}$ containing a $35 \mathrm{mM}$ Tris/ $\mathrm{HCl}, 70 \mathrm{mM} \mathrm{KCl}, \mathrm{pH} 7.5$ buffer. Reconstituted Co(II)-MtoC at $0.4 \mathrm{mg} / \mathrm{ml}$ final concentration was activated by adding $0.5 \mathrm{mM}$ Ti(III)citrate (freshly prepared), $2.3 \mathrm{mM}$ ATP and $0.08 \mathrm{mg} / \mathrm{ml}$ MtoD. Afterwards $2.3 \mathrm{mM}$ 2-methoxybenzoate and $0.4 \mathrm{mg} / \mathrm{ml}$ MtoB were added. As potential methyl group acceptor either $0.8 \mathrm{mM}$ 
$\mathrm{H}_{4} \mathrm{~F}$ (Schircks Laboratories, Switzerland) or $1.7 \mathrm{mM}$ CoM were used. The activity assay was started by addition of $0.03 \mathrm{mg} / \mathrm{ml}$ MtoA. Formation of $\mathrm{Co}(\mathrm{I})-\mathrm{MtoC}$ from $\mathrm{CH}_{3}-\mathrm{Co}$ (III)-MtoC results in a decrease in absorption at $520 \mathrm{~nm}$ which was followed with the UV-vis-spectrophotometer.

For illustration of the whole $O$-demethylation/methyl transfer process, UV-vis spectra were recorded from $250-650 \mathrm{~nm}$ under the latter described conditions after the sequential addition of MtoC, MtoD plus Ti(III) citrate plus ATP, 2-methoxybenzoate plus MtoB, $\mathrm{H}_{4} \mathrm{~F}$ and MtoA.

To measure concentrations of 2-methoxybenzoate and TMB by HPLC an Agilent 1100 HPLC system equipped with a diode array detector (detecting wavelength $230 \mathrm{~nm}$ ) and a Merck C-18e column $(250 \mathrm{~mm} \times 4.6 \mathrm{~mm}, 5 \mu \mathrm{m}$ particle size $)$ was used. The flow rate was $0.75 \mathrm{ml} / \mathrm{min}$ and a linear gradient was applied: $75 \%$ trifluoroacetic acid (TFA; $0.1 \%$ in water), $25 \%$ acetonitrile to $50 \%$ TFA ( $0.1 \%$ in water), $50 \%$ acetonitrile in $15 \mathrm{~min}$. Solutions of TMB, 3-OH-4,5-dimethoxybenzoate, 4-OH-3,5-dimethoxybenzoate, 2-methoxybenzoate and 2hydroxybenzoate in water $(0.1 \mathrm{mg} / \mathrm{ml})$ were used as standards. Twenty microliters of sample was used for injection.

\section{Thermodynamics analyses}

Gibbs free energy yield $(\Delta \mathrm{G})$ was calculated assuming a temperature of $60^{\circ} \mathrm{C}, \mathrm{pH}$ of $7, \mathrm{CO}_{2}(\mathrm{~g})$ of $0.2 \mathrm{bar}, \mathrm{CH}_{4}(\mathrm{~g})$ of 0.2 bar, $1 \mathrm{mM} \mathrm{NH}_{4}^{+}$, and $10 \mathrm{mM}$ for all other compounds. Temperature adjustments were made as described previously [30]. For methoxylated compounds (2-methoxybenzoate and 3,4,5-trimethoxybenzoate), Gibbs free energy of formation $\left(\Delta \mathrm{G}_{\mathrm{f}}\right)$ and enthalpy of formation $\left(\Delta \mathrm{H}_{\mathrm{f}}\right)$ were first estimated for the acid form using the Joback group contribution method [31]. After calculating the $\Delta \mathrm{G}_{\mathrm{f}}$ at $60^{\circ} \mathrm{C}$ using the Van't Hoff equation, the $\Delta \mathrm{G}_{\mathrm{f}}$ of the carboxylate forms at $60^{\circ} \mathrm{C}$ were then calculated using $\mathrm{pK}_{\mathrm{a}}$ estimated by ChemAxon Marvin (https://chemaxon.com/products/marvin). The $\Delta \mathrm{H}_{\mathrm{f}}$ of the carboxylate forms were estimated using $\Delta \mathrm{G}_{\mathrm{f}}$ at 25 and $60^{\circ} \mathrm{C}$ and the Van't Hoff equation. The $\Delta \mathrm{G}$ for methyl transfer from 2-methoxybenzoate, methanol, and methylamine to tetrahydromethanopterin or coenzyme M was calculated by subtracting the $\Delta \mathrm{G}$ of individual reactions in the methanogenesis pathway from the net reaction. $\Delta \mathrm{G}$ for most steps were available from the literature [32-37]. For methylene-tetrahydromethanopterin reduction with $\mathrm{F}_{420} \mathrm{H}_{2}$, the $\Delta \mathrm{G}$ was estimated by adding the values for $\mathrm{F}_{420} \mathrm{H}_{2}$ reduction of $\mathrm{H}^{+}$[38] and $\mathrm{H}_{2}$-driven reduction of methylenetetrahydromethanopterin [39]. Using these $\Delta G$ values, reduction potentials of $-143,-385$, and $-520 \mathrm{mV}$ for coenzyme M/B disulfide, $\mathrm{F}_{420}$ and ferredoxin respectively $[38,40,41]$, ATP hydrolysis $\Delta \mathrm{G}$ of $-60 \mathrm{~kJ} \mathrm{~mol}^{-1}$, transmembrane $\mathrm{H}^{+}$and $\mathrm{Na}^{+}$transport $\Delta \mathrm{G}$ of $-20 \mathrm{~kJ} \mathrm{~mol}^{-1}$, limit (quasi-equilibrium) metabolite concentrations were calculated as described by González-Cabaleiro et al. [42].
Resting cell experiment with $M$. shengliensis ZC-1

M. shengliensis ZC- 1 cells grown in $50 \mathrm{~mL}$ medium (see above) with $10 \mathrm{mM}$ TMB as substrate were harvested under anoxic conditions in the exponential phase and washed with stabilization buffer $\left(2 \mathrm{mM} \quad \mathrm{KH}_{2} \mathrm{PO}_{4} / \mathrm{K}_{2} \mathrm{HPO}_{4}, \quad 2 \mathrm{mM}\right.$ $\mathrm{MgSO}_{4}, 400 \mathrm{mM} \mathrm{NaCl}, 200 \mathrm{mM}$ sucrose, $\mathrm{pH}$ 6.8). The cell pellets were resuspended in $40 \mathrm{ml}$ stabilization buffer (see above) and transferred into $120 \mathrm{ml}$ anaerobic glass bottles (OD 0.1). The cultures were incubated for $30 \mathrm{~min}$ at $65^{\circ} \mathrm{C}$. Afterwards, TMB was added to a final concentration of 10 $\mathrm{mM}$ and the cultures were incubated for $6 \mathrm{~h}$ at $65^{\circ} \mathrm{C}$. The $\mathrm{CH}_{4}$ and $\mathrm{CO}_{2}$ gas produced by the cultures was analyzed every hour by injecting $50 \mu \mathrm{L}$ headspace volume with a gastight glass syringe (Hamilton, Reno, NE) into an Agilent 6890 series gas chromatograph coupled to a mass spectrometer (GC-MS) (Agilent, Santa Clara, CA) equipped with a Porapak Q column heated at $80^{\circ} \mathrm{C}$. For calculating the percentage of $\mathrm{CH}_{4}$ and $\mathrm{CO}_{2}$ in the culture headspace a calibration curve was generated by injecting different volumes of calibration gas (Linde Gas Benelux) that contained $1 \% \mathrm{CO}_{2}$ and $1 \% \mathrm{CH}_{4}$ into the GC-MS. The $\mathrm{CO}_{2}$ values (in \%) were corrected for the $\mathrm{CO}_{2}$ in the medium in form of $\mathrm{HCO}_{3}{ }^{-}$by measuring the headspace $\mathrm{CO}_{2}$ in $40 \mathrm{ml}$ buffer before and after acidification with $\mathrm{HCl}$. The experiment was performed in triplicate.

\section{$\left[{ }^{13} \mathrm{C}\right]$ labeled bicarbonate experiment}

M. shengliensis ZC-1 cells were incubated in $50 \mathrm{~mL}$ medium (see above; instead of $\left[{ }^{12} \mathrm{C}\right]$ bicarbonate, $\left[{ }^{13} \mathrm{C}\right]$ bicarbonate was used) with $10 \mathrm{mM}$ TMB or $75 \mathrm{mM} \mathrm{MeOH}$ as substrate at $65^{\circ} \mathrm{C}$ in quadruplicates. This experiment has to be interpreted in a qualitative and not a quantitative way as not all of the $\mathrm{CO}_{2}$ present in the cultures is $\left[{ }^{13} \mathrm{C}\right] \mathrm{CO}_{2}$. The medium was sparged with $\mathrm{N}_{2}: \mathrm{CO}_{2}(80: 20)$ and the $\mathrm{CO}_{2}$ in the gas was not $\left[{ }^{13} \mathrm{C}\right]$ labeled. The carbonate buffering system is required for growth of those cultures. The $\left[{ }^{12} \mathrm{C}\right]-$ and $\left[{ }^{13} \mathrm{C}\right]-\mathrm{CH}_{4}$ and $\mathrm{CO}_{2}$ gas produced by the cultures was analyzed every day for a period of 7 days by injecting $50 \mu \mathrm{L}$ headspace volume into a GC-MS (see above). The ratio of $\left[{ }^{12} \mathrm{C}\right]$ and $\left[{ }^{13} \mathrm{C}\right] \mathrm{CH}_{4}$ was calculated for all cultures to different time points (day 4 to 7 ). The $1 \%\left[{ }^{13} \mathrm{C}\right]-\mathrm{CH}_{4}$ naturally present in $\mathrm{CH}_{4}$ was subtracted from the $\left[{ }^{13} \mathrm{C}\right]-\mathrm{CH}_{4}$ values.

\section{Results and discussion}

\section{Genomic analysis}

Anaerobic degradation of methyl compounds in both Archaea and Bacteria begins with the transfer of the methyl group to a physiological $\mathrm{C}_{1}$ carrier. In both systems, a 
substrate-specific methyltransferase (MT1; Eq. 1) transfers the methyl group to a corrinoid protein $(\mathrm{CP})$ and another methyltransferase (MT2 Eq. 2) performs a subsequent transfer to a physiological $\mathrm{C}_{1}$ carrier-coenzyme $\mathrm{M}(\mathrm{CoM})$ for Archaea and tetrahydrofolate $\left(\mathrm{H}_{4} \mathrm{~F}\right)$ for Bacteria $[14,43]$. Both require two methyltransferases, one $\mathrm{CP}$, and an activating enzyme to recycle adventitiously oxidized CPs $[44,45]$.

$\mathrm{CH}_{3}-\mathrm{X}+\mathrm{Co}(\mathrm{I})-\mathrm{CP}+\mathrm{H}^{+} \rightarrow \mathrm{CH}_{3}-\mathrm{Co}(\mathrm{III})-\mathrm{CP}+\mathrm{H}-\mathrm{X}$

$\mathrm{CH}_{3}-\mathrm{Co}(\mathrm{III})-\mathrm{CP}+\mathrm{Y}-\mathrm{H} \rightarrow \mathrm{CH}_{3}-\mathrm{Y}+\mathrm{Co}(\mathrm{I})-\mathrm{CP}+\mathrm{H}^{+}$

\section{$\mathrm{Y}=\mathrm{CoM}$ or $\mathrm{H}_{4} \mathrm{~F}$}

M. shengliensis can metabolize $\mathrm{MeOH}$ and mono-, di-, and tri-methylamines and encodes the necessary substratespecific CPs, MT1s, and MT2s (Fig. 1a, b; Supplementary Table S1). However, with help of an extensive genome analysis we identified an operon in the $M$. shengliensis AmaM and ZC-1 genomes encoding a putative methyltransferase complex of unknown specificity that has previously been overlooked. This operon includes a CP (Amam_00017; BP07_RS03260), three methyltransferases (Amam_00018, Amam_00019, and Amam_00021; BP07_ 03250, BP07_03255, and BP07_RS03240), and a corrinoid activator protein (Amam_00022; BP07_RS03235) distantly related to known methanogen methyltransferase components (Fig. 1a-c, and Supplementary Fig. S1).

Although an archaeal $O$-demethylase/methyltransferase system for methoxylated aromatic compounds has not been described previously, some genes identified in this study and mentioned above show homology with counterparts in the bacterial Mtv $O$-demethylation system present in the homoacetogenic bacterium Moorella thermoacetica (Pierce et al. [60]; Fig. 1a, b; Supplementary Table S1). Amam_00017 (BP07_RS03260) and Amam_00018/19 (BP07_RS03255/50) are closely related to the CP (MtvC) and vanillate-specific MT1 (MtvB) of the three-component Moorella thermoacetica vanillate $O$-demethylase system MtvABC [46], indicating involvement of the operon in $\mathrm{ArOCH}_{3}$ demethylation. We also found Amam_00017, 18, and 19 homologs in the genomes of other $\mathrm{ArOCH}_{3}$-catabolizing bacterial anaerobes whose methyltransferases have yet to be identified (Fig. 1c) [47-51]. Based on phylogenetic comparison of the archaeal and bacterial systems, Archaea likely acquired the $O$-demethylase (MtvB) and corresponding $\mathrm{CP}$ (MtvC) for methoxylated aromatic compound metabolism through horizontal gene transfer from Bacteria (Fig. 1a, b). The genes putatively involved in methoxydotrophic growth are also present in other archaea like Archaeoglobus fulgidus and the hydrogenotrophic methanogens Methanolacinia petrolearia and
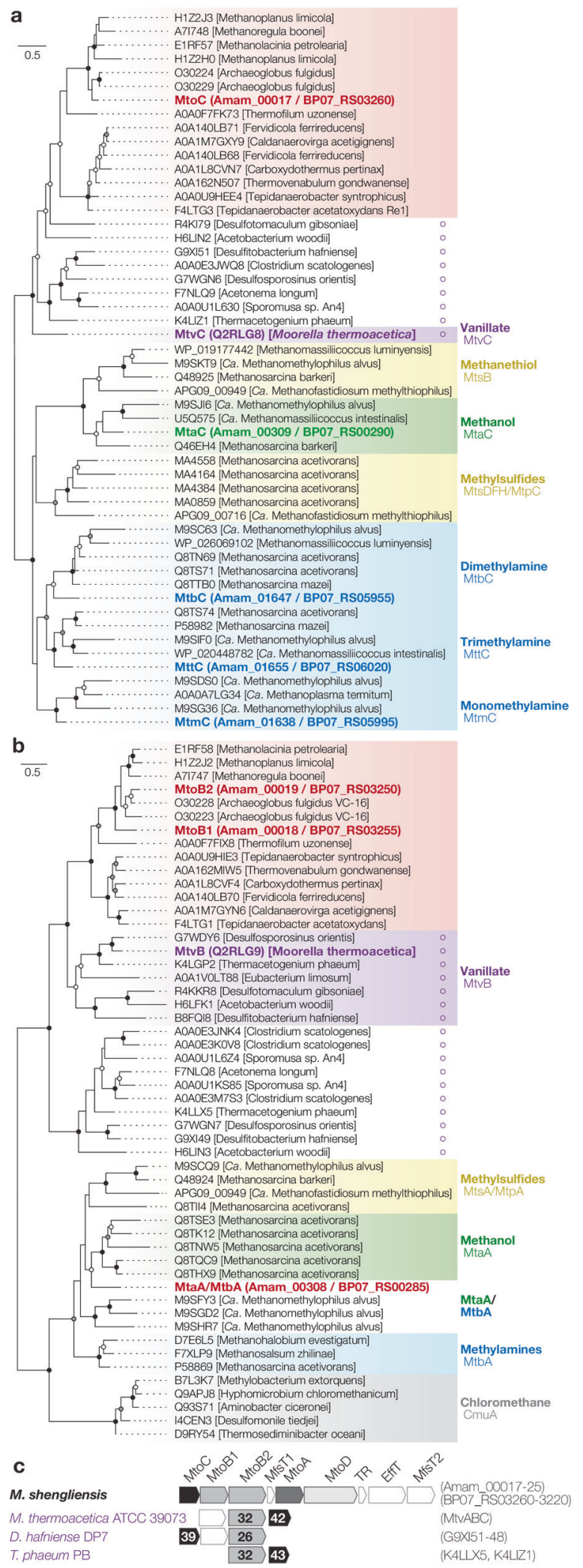

Methanothermobacter tenebrarum (Fig. 1a, b), indicating that the trait for methoxydotrophic growth might be more prevalent among archaea than previously thought. 
Fig. 1 M. shengliensis AmaM and ZC-1 corrinoid protein and methyltransferase phylogeny. a A phylogenetic tree of AmaM methyltransferase corrinoid proteins (red and bolded) and homologs were generated through sequenced alignment via MAFFT v7.394 and tree calculation via RAxML-NG v0.5.1b. The homologs include those specific to vanillate (MtvC; purple), $\mathrm{MeOH}$ (e.g., MtaC; green), methylated thiols (e.g., MtsB; yellow), and methylamines (e.g., MtmC; blue). For methyltransferase corrinoid proteins fused with their partner methyltransferase, only the cobalamin-binding region was extracted for this alignment. In addition, a novel cluster of bacterial methyltransferases is shown, including those from $\mathrm{ArOCH}_{3}$-metabolizing anaerobes (indicated with purple circles). Bootstrap values are shown for 200 iterations $(>90 \%$ black, $>70 \%$ gray, $>50 \%$ white). b Phylogenetic tree of MtaA/CmuA family (TIGR01463, cd03307, and IPR006360) and MtvB-related methyltransferases, including those from $M$. shengliensis (red and bolded) and $M$. thermoacetica (purple and bolded). MT2 for $\mathrm{MeOH}$ (e.g., MtaA; green), methylamine (e.g., MtbA; blue), and $\mathrm{MeOH} /$ methylamine bifunctionally; bifunctional MT1/MT2 for methylated thiols (e.g., MtsA; yellow); and MT1 for chloromethane (gray) are shown. Methyltransferases affiliated with $\mathrm{ArOCH}_{3}$-metabolizing anaerobes (purple circles) form a novel cluster. c The operon encoding the novel corrinoid protein (MtoC) with methyltransferases (MtoB1, MtoB2, and MtoA) and corrinoid protein activase (MtoD) along with potential aromatic compound transporters (MfsT MFS transporter, EffT Efflux transporter) and a transcriptional regulator (TR). Operons identified in bacterial $\mathrm{ArOCH}_{3}$ metabolizers are also shown with amino acid sequence percent identity with MtoC and MtoB2.

As the above methyltransferases and $\mathrm{CP}$ are cytosolic, $M$. shengliensis requires transporters for the uptake of methoxylated aromatic compounds. Although specific transporters for aromatic compounds have not been found for methanogens, previous studies have characterized several bacterial aromatic acid: $\mathrm{H}^{+}$symporters belonging to the major facilitator superfamily (MFS) [52]. This includes PcaK from Pseudomonas putida [53], TfdK from Ralstonia eutropha [54], BenK, VanK, PcaK, and MucK from Acinetobacter sp. ADP1 [55-57] and MhpT from Escherichia coli [58]. We also identified genes encoding MFS transporters adjacent to the aforementioned methyltransferases (Fig. 1c and Supplementary Table S1) and suspect that they drive aromatic compound transport for $M$. shengliensis.

\section{Novel demethoxylation pathway involves methyl transfer to tetrahydromethanopterin}

To verify involvement of the aforementioned gene cluster in $\mathrm{ArOCH}_{3}$ metabolism, we compared AmaM transcriptomes during methanogenesis from $\mathrm{ArOCH}_{3}$ (i.e., $p$-methoxybenzoate $[\mathrm{MB}]$ and 3,4,5-trimethoxybenzoate [TMB]) and methyl compounds (i.e., $\mathrm{MeOH}$ and trimethylamine) as well as the $\mathrm{ZC}-1$ transcriptomes and proteomes of $\mathrm{ArOCH}_{3}$ (i.e., TMB) - and cells grown on methyl compounds (i.e., $\mathrm{MeOH})$. For AmaM, the MtvB-related methyltransferase MtoB2, another methyltransferase designated MtoA, reductive activase MtoD, and an MFS transporter MfsT1 were consistently strongly upregulated during growth on methoxylated aromatic compounds ( $p$ value $<0.05$; Fig. 2 and Supplementary Tables S1 and S2). Similarly, ZC-1 upregulated MtoB1, MtoB2, CP MtoC, reductive activase MtoD, and MfsT1 in the transcriptomes and or proteomes ( $p$ value $<0.05$; Fig. 2 and Supplementary Table S1). The novel $M$. shengliensis methyltransferase genes displayed one of the highest increases in expression among all genes (Fig. 2 and Supplementary Table S1), up to 90-fold. We propose that Amam_00017 22/BP07_RS03235 60 collectively function as a novel $\mathrm{ArOCH}_{3}$-specific $O$-demethylase/ methyltransferase system, tentatively termed the Mto system based on the nomenclature used by Sauer and Thauer for methanogenic methyltransferases [59], and the adjacent transporters as $\mathrm{ArOCH}_{3}$ uptake or byproduct aromatic compound efflux proteins. We further propose that Amam_00018/BP07_RS03255 and Amam_00019/BP07_ RS03250 function as $\mathrm{ArOCH}_{3}$-specific MT1 (MtoB1 and MtoB2 respectively) and Amam_00017/BP07_RS03260 as the corresponding methyl-carrying $\mathrm{CP}$ (MtoC), based on the aforementioned similarity with Moorella thermoacetica MtvB and MtvC (Fig. 1). Together, $\operatorname{MtoB}(1 / 2)$ and MtoC likely accomplish the first step in $\mathrm{ArOCH}_{3} O$-demethylation (Eq. 3).

$\mathrm{ArOCH}_{3}+\mathrm{Co}(\mathrm{I})+\mathrm{H}^{+} \rightarrow \mathrm{CH}_{3}-\mathrm{Co}(\mathrm{III})-\mathrm{MtoC}+\mathrm{ArOH}$

As described before, M. shengliensis can use a broad range of different methoxylated aromatics for growth [6]. The $O$-demethylase proteins MtoB1 (Amam_00018/ BP07_RS03255; $48 \mathrm{kDa}$ ) and MtoB2 (Amam_00019/ BP07_RS03250; $47 \mathrm{kDa}$ ) have a sequence similarity of $57 \%$ to each other (NCBI BLASTp). This dissimilarity might hint towards different substrate affinities of the two proteins. In the first step of methoxydotrophic methanogenesis, through $O$-demethylation via the MtoB proteins, the methyl group is most likely transferred to the cobalt containing CP MtoC (22 kDa; N-terminal Coenzyme $\mathrm{B}_{12}$ binding site [Prosite: https://prosite.expasy.org]). MtoD (Amam_00019/BP07_RS03235; $68 \mathrm{kDa}$ ) is predicted to perform activation of the $\mathrm{CP}$, a process necessary for catalytic activity of the $\mathrm{CP}$ in both acetogens and methanogens. This corrinoid activation protein MtoD harbors an N-terminal 2Fe-2S binding site (Prosite: https://prosite.expasy.org), a feature more similar to those of acetogens than methanogens (two C-terminal $4 \mathrm{Fe}-4 \mathrm{~S}$ clusters) [28].

The next step is methyl transfer from $\mathrm{CH}_{3}-\mathrm{MtoC}$ to a physiological $\mathrm{C}_{1}$ carrier by a methyl transferase (MT2). In methylotrophic methanogens, the methyl group is transferred from the $\mathrm{CP}$ to $\mathrm{CoM}$ via the methyl transferase MtaA when grown on methanol (Fig. 3). In the acetogen Moorella thermoacetica the methyl transferase MtvA transports the methyl group from the $\mathrm{CP}$ to $\mathrm{H}_{4} \mathrm{~F}$ [46]. M. shengliensis does not 
Fig. 2 Comparison of gene expression during growth on methylated and methoxylated substrates. (left) Gene expression of the novel AmaM/ ZC-1 corrinoid protein and methyltransferase operon, methanogenesis pathways, and electron transduction (see Supplementary Table S1 for abbreviations). RPKM (reads per kilobase transcript per million mapped reads) values are normalized to the average ribosomal protein RPKM under methanogenesis from $\mathrm{MeOH}$, trimethylamine (TMA), 2methoxybenzoate (MB), and trimethyoxybenzoate (TMB). (right) The ratios of gene expression between $\mathrm{ArOCH}_{3}$ and methylated compound-fed conditions are shown ( $p$ value $<$ 0.05 marked with dot). For ZC-

1 , dots are shown if at least two TMB-grown cultures show significantly different RNA expression levels ( $p$ value $<$ 0.05) from the $\mathrm{MeOH}$-grown cultures (see Supplementary Table S1). Similarly, triangles are shown if significant differences in protein expression levels were observed ( $p$ value $<$ $0.05)$. For entries spanning multiple genes, expression levels of specific subunits are shown as indicated on the right-hand side.

\section{Methoxy activation}

$\mathrm{ArOCH}_{3}$ methyltransferase

-associated activase

-associated transporters

\section{Gene expression levels (RPKM)}

AmaM

ZC-1

Expression level ratios

AmaM ZC-1

齐

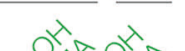
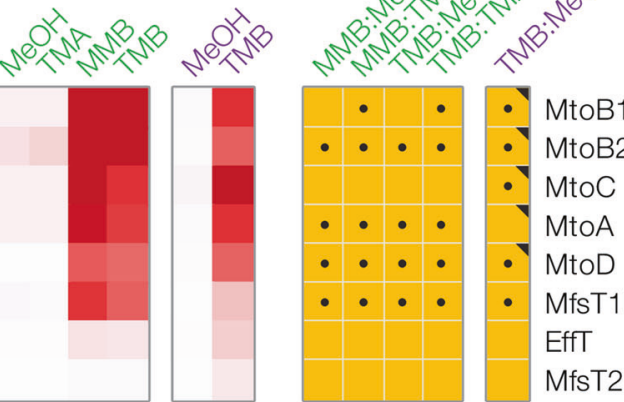

Methanogenesis

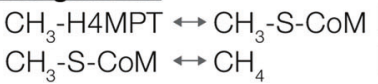

$\mathrm{CH}_{3}-\mathrm{H} 4 \mathrm{MPT} \leftrightarrow \mathrm{CO}_{2}$
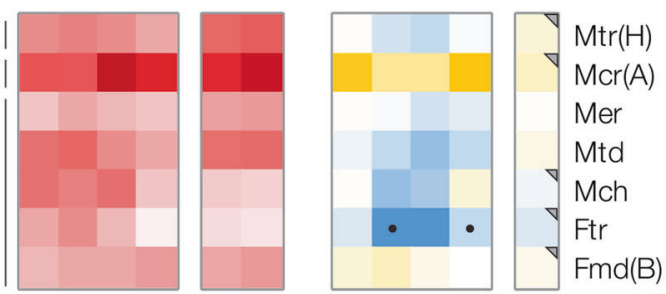

\section{Electron metabolism}

Heterodisulfide reductase (mem.)

$\mathrm{F}_{420}$-dep. oxidoreductase

Heterodisulfide reductase (cyt.)
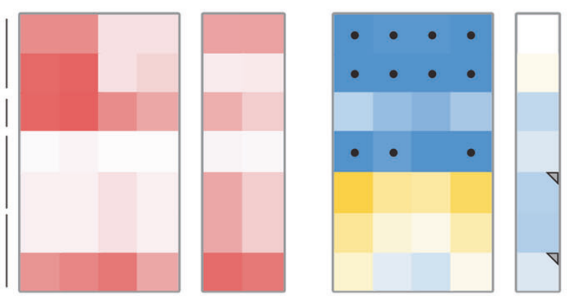

$\mathrm{Fpx}(\mathrm{B})$

Fpx(M)

$\operatorname{Hdr}(\mathrm{E})$

FrhB2

FrhB1

$\mathrm{Hdr}(\mathrm{A} 2)$

$\operatorname{Hdr}(\mathrm{A} 1)$

Cation transport

$\mathrm{Na}^{+} / \mathrm{H}^{+}$antiporter
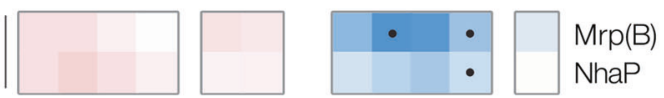

\section{Acetate metabolism}

Pyruvate:Fd oxidoreductase

Bifunctional $\mathrm{CO}$ dehydrogenase
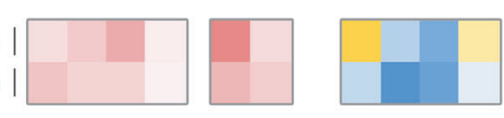

Por(A)

$\operatorname{Cdh}(\mathrm{A})$

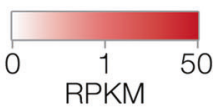

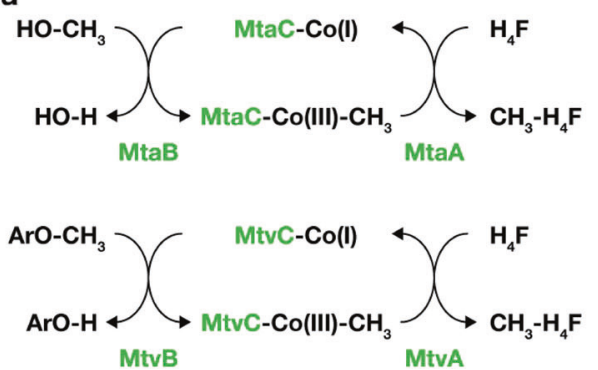

Fig. 3 Demethylation and demethoxylation pathways in acetogenic bacteria and methanogenic archaea. a Demethylation and demethoxylation pathways as described for the acetogenic bacterium Moorella thermoacetica, modified from Pierce et al. [60]. b Demethylation

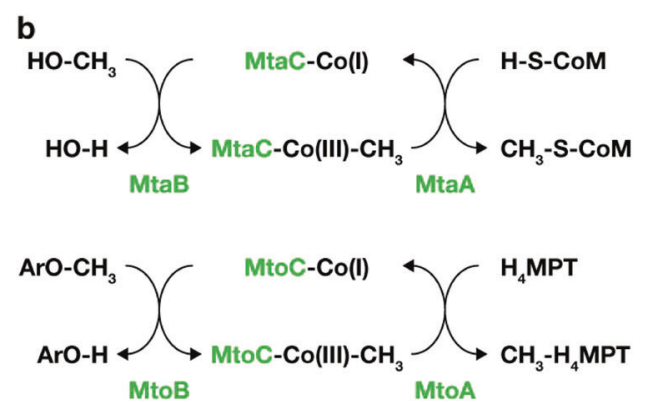

and tentative demethoxylation pathways in methanogenic archaea. Co(I/ III): oxidation state of the cobalamin carried by the cobalamin binding protein $\mathrm{MtoC}, \mathrm{H}_{4} \mathrm{MPT}$ : tetrahydromethanopterin. 


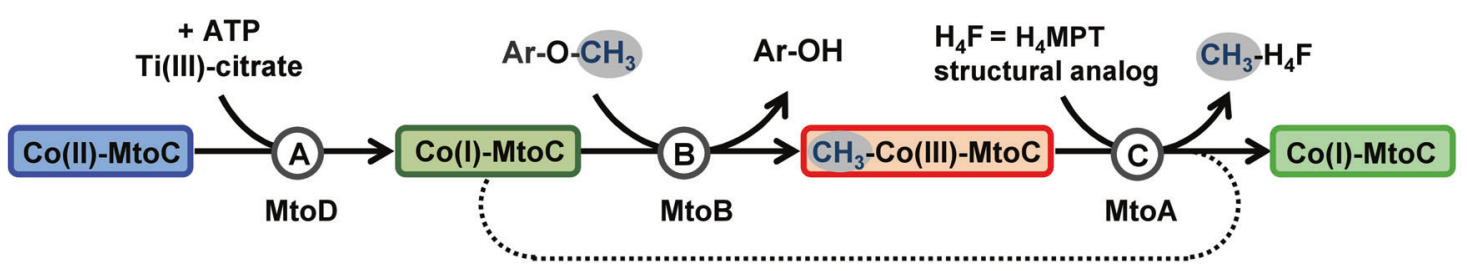

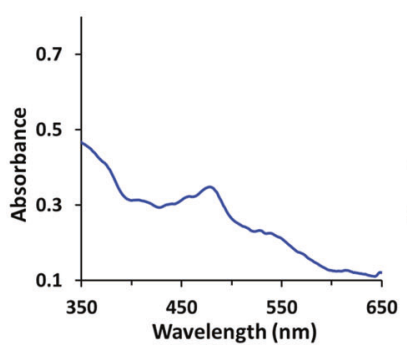

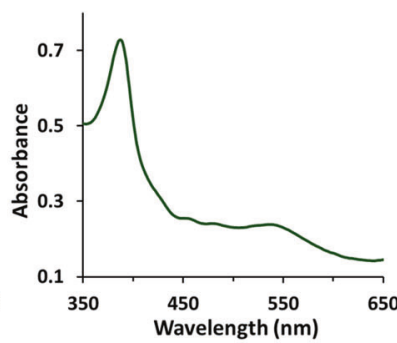

Fig. $4 \boldsymbol{O}$-demethylation and methyl transfer conducted by Mto proteins. Reaction A: MtoD, ATP and titanium (III) citrate are required for activation of $\mathrm{MtoC}$ from the $\mathrm{Co}$ (II) state (blue) to the active $\mathrm{Co}(\mathrm{I})$ state (dark green). Reaction B: MtoB transfers the methyl group of the methoxy compound $\left(\mathrm{Ar}-\mathrm{O}-\mathrm{CH}_{3}\right)$ to $\mathrm{Co}(\mathrm{I})-\mathrm{MtoC}$ resulting in methylated $\mathrm{Co}$ (III)-MtoC (red). The MtoB activities with 2methoxybenzoate (MB) and TMB are shown in Fig. S2A. With methanol or trimethylamine as substrate no activity could be observed. Conversion of TMB to 3-OH-4,5-dimethoxybenzoate was confirmed by HPLC (Fig. S3). Reaction C: For measuring MtoA activity, the

encode an $m t v A$-like gene and $m t a A$ is neither upregulated under growth on methoxylated compounds nor part of the identified methoxydotrophy gene cluster. Instead, an $m t r H$-like gene (Amam_00021/BP07_RS03240) is part of the aforementioned operon and is highly upregulated under methoxydotrophic growth in M. shengliensis. This gene is not homologous to any known MT2 and rather relates to methyltransferase family PF02007: methyl-tetrahydromethanopterin ( $\mathrm{H}_{4}$ MPT):CoM methyltransferase (Mtr) subunit $\mathrm{H}$ (MtrH; $41 \%$ peptide similarity to that of Methanosarcina barkeri) (Supplementary Fig. S1). Although MtrH (subgroup I) is part of the membrane-bound Mtr complex found in methanogens, the identified M. shengliensis MtrH homolog Amam_00021/ BP07_RS03240 relates more to MtrH-related proteins (e.g., subgroup III) that do not form such a complex and are found in non-methanogenic archaea (e.g., Archaeoglobus fulgidus) and methylotrophic bacteria Desulfitobacterium hafniense or Acetobacterium woodii [61] (i.e., organisms that neither synthesize nor utilize CoM). MtrH in Desulfitobacterium hafniense has been described as a methylcorrinoid:tetrahydrofolate methyltransferase [62]. As Amam_00021/BP07_RS03240 is upregulated together with the neighboring MtoC, MtoB1, and MtoB2 during $\mathrm{ArOCH}_{3}$ metabolism, we hypothesize that the gene product serves as an $\mathrm{CH}_{3}$-(CoIII)-MtoC: $\mathrm{H}_{4} \mathrm{MPT}$ methyltransferase (Eq. 4), tentatively named MtoA. Together MtoAB $(1 / 2) \mathrm{C}$ might catalyze complete methyl transfer from $\mathrm{ArOCH}_{3}$ to $\mathrm{H}_{4} \mathrm{MPT}$ (Eq. 5) and MtoD is a corresponding corrinoid activation protein required for sustained methyltransferase
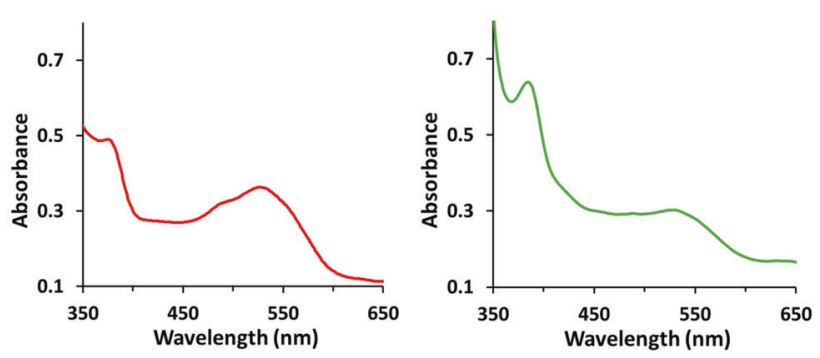

$\mathrm{H}_{4}$ MPT structural analog $\mathrm{H}_{4} \mathrm{~F}$ was used. We got strong evidence that MtoA transfers the methyl group from methylated Co(III)-MtoC (red) to $\mathrm{H}_{4} \mathrm{~F}$ thereby producing $\mathrm{Co}(\mathrm{I})-\mathrm{MtoC}$ (light green). The activity is shown in Fig. S2B. In M. shengliensis $\mathrm{H}_{4} \mathrm{MPT}$ and not $\mathrm{H}_{4} \mathrm{~F}$ is most likely the methyl group acceptor as $M$. shengliensis does not have the genomic capacity to synthesize $\mathrm{H}_{4} \mathrm{~F}$. Also, the methyl-transfer reaction is not occurring if $\mathrm{CoM}$ is used instead of $\mathrm{H}_{4} \mathrm{~F}$ (Fig. S2B). All bottom panels correspond to UV/visible spectra measured after each reaction reflecting the different states of the cobalamin carried by MtoC.

activity (Eq. 6):

$$
\begin{aligned}
& \mathrm{CH}_{3}-\mathrm{Co}(\mathrm{III})-\mathrm{MtoC}+\mathrm{H}_{4} \mathrm{MPT} \rightarrow \mathrm{CH}_{3}-\mathrm{H}_{4} \mathrm{MPT} \\
&+\mathrm{Co}(\mathrm{I})-\mathrm{MtoC} \\
& \mathrm{ArOCH}_{3}+\mathrm{H}_{4} \mathrm{MPT} \rightarrow \mathrm{ArOH}+\mathrm{CH}_{3}-\mathrm{H}_{4} \mathrm{MPT} \\
& \mathrm{Co}(\mathrm{II})-\mathrm{MtoC}+\mathrm{ATP}+\mathrm{H}_{2} \mathrm{O}+\mathrm{e}^{-} \rightarrow \mathrm{Co}(\mathrm{I})-\mathrm{MtoC} \\
&+\mathrm{ADP}+\mathrm{P}_{\mathrm{i}}
\end{aligned}
$$

To verify the function of the Mto proteins from $M$. shengliensis in $O$-demethylation and methyl transfer, we purified the Mto proteins and analyzed them by UV-vis spectroscopy and enzyme activity assays (Fig. 4 and Supplementary Fig. S2).

MtoC exhibits different UV-vis spectroscopic features depending on the oxidation state of its cobalamin cofactor. In the inactive Co(II) state, the UV-vis spectrum shows a peak at around $480 \mathrm{~nm}$ (Fig. 4, before reaction A). The corrinoid activator MtoD can reactivate the Co(II) state of MtoC by reducing the cobalamin to the active $\mathrm{Co}(\mathrm{I})$ state with the use of ATP and titanium (III) citrate (Fig. 4, reaction $\mathrm{A})$. The active $\mathrm{Co}(\mathrm{I})$ state exhibits a peak at around $390 \mathrm{~nm}$ (gamma band). When MtoB and the methoxylated aromatic compound are added to the enzyme assay mixture the methyl group is transferred to the cobalamin (Fig. 4, reaction B), as also shown by HPLC (Supplementary 
Fig. S3). The formation of methyl-Co(III) provokes the disappearance of the peak at $390 \mathrm{~nm}$ and the appearance of a new peak at $520 \mathrm{~nm}$. The demethylation of MtoC by MtoA was observed when tetrahydrofolate $\left(\mathrm{H}_{4} \mathrm{~F}\right)$, a C1carrier analogous to $\mathrm{H}_{4} \mathrm{MPT}$, was added (Fig. 4, reaction C). This reaction can be followed by the decrease of absorbance at $520 \mathrm{~nm}$ and the increase of absorbance at $390 \mathrm{~nm}$, which is explained by a switch back to the $\mathrm{Co}(\mathrm{I})$ state. As $\mathrm{H}_{4} \mathrm{~F}$ instead of the native methyl acceptor $\mathrm{H}_{4} \mathrm{MPT}$ is used in the assay no specific activity value for MtoA could be accurately determined. By HPLC analysis of the methoxy compounds and their hydroxylated derivatives we observed that roughly $2.2 \%$ of the methoxy compound is converted (i.e., about $51 \mu \mathrm{M}$ of the initial $2.3 \mathrm{mM}$ TMB; Supplementary Fig. S3), which agrees with the concentration of the methyl-acceptor MtoC in the assay mixture $(\sim 55 \mu \mathrm{M})$. The MtoB activity with 2-methoxybenzoate (MB) was found to be $0.87 \pm 0.04 \mu \mathrm{mol} \mathrm{Co}$ (III) formed per min and per mg of MtoB and with TMB $0.76 \pm 0.04 \mu \mathrm{mol}$ of $\mathrm{Co}$ (III) formed per min and per $\mathrm{mg}$ of MtoB (see also Supplementary Fig. S2A). The specific activity values of the $O$ demethylase of Acetobacterium dehalogenans measured with vanillate and isovanillate are 0.43 and $0.65 \mu \mathrm{mol}$ Co (III) formed per min and per mg MT1 respectively, for example [28].

With those experiments we showed that the $O$-demethylation and methyl transfer reaction are indeed catalyzed by the Mto proteins and that this system works in a similar way as shown for methoxydotrophic bacteria such as Moorella thermoacetica [46] or A. dehalogenans [28]. We could identify MtoB (WP_042685515.1) as the $O$-demethylase catalysing the methyl transfer from the methoxy compound to Co(I)-MtoC. After accepting the methyl group from MtoB, MtoC could not be demethylated by MtoA in the presence of HS-CoM, the conventional methyl-acceptor for methylotrophic methanogenenesis. On the other hand, MtoC demethylation by MtoA could be observed when the $\mathrm{H}_{4}$ MPT structural analog $\mathrm{H}_{4} \mathrm{~F}$ was present. Given that $M$. shengliensis can only synthesize $\mathrm{H}_{4} \mathrm{MPT}$ and not $\mathrm{H}_{4} \mathrm{~F}$ (e.g., absence of bacterial dihydrofolate reductase), this gives us strong evidence that $\mathrm{H}_{4} \mathrm{MPT}$, rather than HS-CoM, should accept the methyl group from $\mathrm{CH}_{3}-\mathrm{Co}(\mathrm{III})-\mathrm{MtoC}$ in $M$. shengliensis.

Such a $\mathrm{H}_{4}$ MPT-dependent methyl transfer would be the first of its kind though, in some aspects, comparable to other pterin-dependent methyl activation pathways- $-\mathrm{H}_{4} \mathrm{MPT} /$ $\mathrm{H}_{4} \mathrm{~F}$-dependent acetyl-CoA decarbonylation and $\mathrm{H}_{4} \mathrm{~F}-$ dependent acetogenic methyl transfer pathway [63]. If the Methermicoccus methyltransferase system is indeed dependent on the archaeal equivalent of $\mathrm{H}_{4} \mathrm{~F}$, this may be because the archaeal ability to degrade methoxylated aromatic compounds likely originated in C1-metabolizing Firmicutes, based on the topology of the MtoB and MtoC phylogenetic trees (Fig. 1a, b). The proposed transfer of the
$\mathrm{ArOCH}_{3}$-derived methyl group to $\mathrm{H}_{4} \mathrm{MPT}$ rather than $\mathrm{CoM}$ would significantly influence the energetics of methanogenesis. Based on thermodynamic calculations we suggest the following hypotheses regarding the energy metabolism of methoxydotrophic methanogens: typical methylotrophic methanogenesis disproportionates $\mathrm{CH}_{3}-\mathrm{S}-\mathrm{CoM}$ to $1 / 4 \mathrm{CO}_{2}$ and $3 / 4 \mathrm{CH}_{4}$. In this pathway $\left(4 \mathrm{CH}_{3} \mathrm{X}+2 \mathrm{H}_{2} \mathrm{O} \rightarrow \mathrm{CO}_{2}+\right.$ $\left.3 \mathrm{CH}_{4}+4 \mathrm{HX}\right), \mathrm{CH}_{3}-\mathrm{S}-\mathrm{CoM}$ oxidation to $\mathrm{CO}_{2}$ requires an energy input $\left(\sim 2 \mathrm{Na}^{+}\right.$transported in for transferring the methyl group from $\mathrm{CoM}$ to $\mathrm{H}_{4} \mathrm{MPT}$; Fig. 5) but electron transfer from this oxidation to reduction of $\mathrm{CH}_{3}$-S-CoM to $\mathrm{CH}_{4}$ allows energy recovery $\left(\sim 8 \mathrm{H}^{+}\right.$transported out, assuming all $\mathrm{F}_{420} \mathrm{H}_{2}$ is re-oxidized via Fpo-related $\mathrm{Fd}$ : methanophenazine (Mp) oxidoreductase (Fpl); Fig. 5). Assuming each $\mathrm{H}^{+} / \mathrm{Na}^{+}$transported across the membrane stores $20 \mathrm{~kJ}$ per mol, this yields a net energy gain of $120 \mathrm{~kJ}$ per four mol methyl substrate. If methoxydotrophic methanogenesis follows an analogous pathway with an entry point at $\mathrm{CH}_{3}-\mathrm{H}_{4} \mathrm{MPT}\left(\mathrm{CH}_{3}-\mathrm{H}_{4} \mathrm{MPT}\right.$ disproportionation to $1 / 4 \mathrm{CO}_{2}$ and $3 / 4 \mathrm{CH}_{4}$ ), oxidation of $\mathrm{CH}_{3}-\mathrm{H}_{4} \mathrm{MPT}$ to $\mathrm{CO}_{2}$ would not incur any energetic cost, while reduction of $\mathrm{CH}_{3}-\mathrm{H}_{4} \mathrm{MPT}$ to $\mathrm{CH}_{4}$ would generate energy $\left(\sim 6 \mathrm{Na}^{+}\right.$transported out; Fig. 5). Combined with the energy gain from electron transfer $\left(\sim 8 \mathrm{H}^{+}\right.$transported out), such metabolism would yield a net energy gain of $280 \mathrm{~kJ}$ per four mol methoxylated substrate. Based on such energetics, $M$. shengliensis methylotrophic and methoxydotrophic methanogenesis would, in theory, respectively reach roughly $40 \%$ and $94 \%$ thermodynamic efficiency (e.g., 40.0, 41.2, and $93.7 \%$ for $\mathrm{MeOH}[-299.7 \mathrm{~kJ}]$, monomethylamine $[-291.0 \mathrm{~kJ}]$, and 2-methoxybenzoate $[-298.9 \mathrm{~kJ}]$ correspondingly at $60^{\circ} \mathrm{C}, \mathrm{pH} 7,0.2 \mathrm{~atm} \mathrm{CO}_{2}, 0.2 \mathrm{~atm} \mathrm{CH}_{4}$, $1 \mathrm{mM} \mathrm{NH}_{4}{ }^{+}$, and $10 \mathrm{mM}$ for all other compounds; see also Supplementary Table S3). However, most anaerobes work at efficiencies around $25-50 \%$ and efficiencies above $80 \%$ are highly improbable [64], suggesting that methoxydotrophic methanogenesis through such a pathway would be impossible. To operate at an energetic efficiency that organisms can physicochemically achieve, methoxydotrophic methanogenesis most likely takes an alternative route that recovers a lesser amount of energy. As an analogous phenomenon of trading off energy yield for thermodynamic driving force, one can look at glycolysiscompared to the Embden-Meyerhof-Parnas pathway, the Entner-Douduroff pathway sacrifices half of the ATP yield partly to minimize thermodynamic bottlenecks and prioritize thermodynamic feasibility $[65,66]$

Supporting the possibility of an alternative route (i.e., not simple disproportionation to $\mathrm{CO}_{2}$ and $\mathrm{CH}_{4}$ ), we obtained evidence that methylotrophic and methoxydotrophic methanogenesis behave differently metabolically-while nearly all $\mathrm{CH}_{4}$ (96.4\%) produced from strain AmaM methylotrophic methanogenesis originated from the 


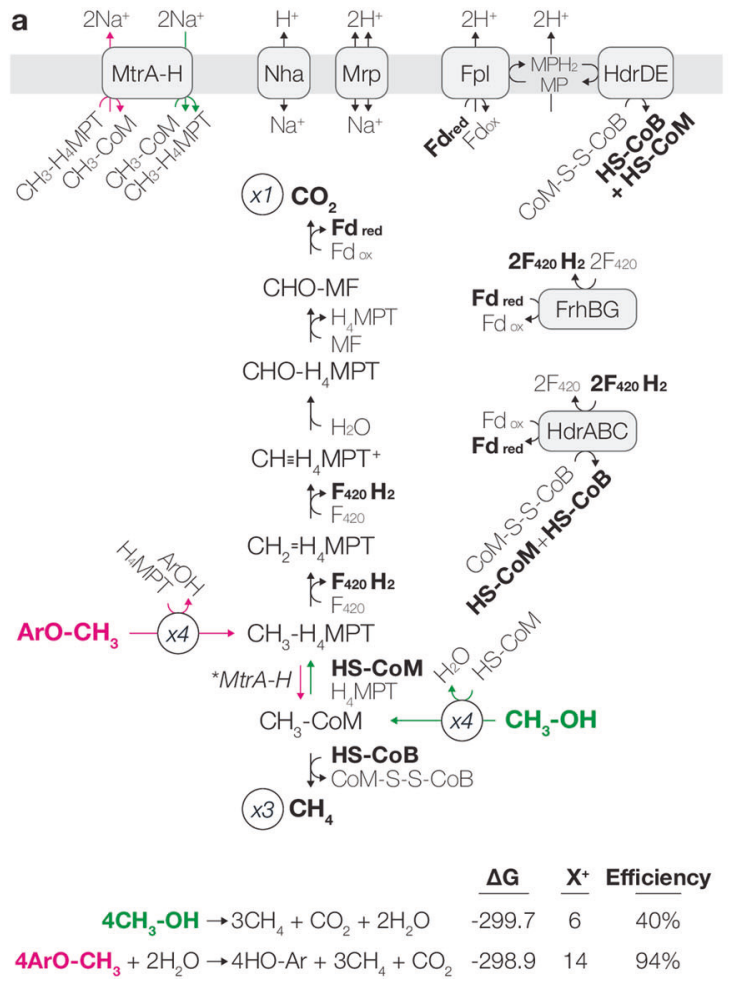

Fig. 5 Comparison of $\mathrm{CH}_{3}-\mathrm{CoM}$ - and hypothetical $\mathrm{CH}_{3}-\mathrm{H}_{4} \mathrm{MPT}$ disproportionating methanogenesis based on (a) energetics and (b) expression. a Reactions and reaction directions unique to $\mathrm{MeOH}$ (green) or 2-methoxybenzoate (pink) decomposition are shown. Below are the estimated Gibbs free energy $(\Delta \mathrm{G})$ and the predicted energy yield (in terms of $\mathrm{H}^{+} / \mathrm{Na}^{+}$extruded across the membrane, assuming the typical scheme of methylotrophic methanogenesis is followed) and thermodynamic efficiency of the shown methanogenesis pathways. $\Delta \mathrm{G}$ was calculated assuming $60^{\circ} \mathrm{C}, \mathrm{pH} 7,0.2 \mathrm{~atm} \mathrm{CO}_{2}, 0.2 \mathrm{~atm} \mathrm{CH}_{4}, 1$ $\mathrm{mM} \mathrm{NH}_{4}{ }^{+}$, and $10 \mathrm{mM}$ for all other compounds. b Comparison of gene/protein expression of $M$. shengliensis grown on methoxylated

methylated substrate (as was also observed for Methanosarcina barkeri [98-99\% $\mathrm{CH}_{4}$ from methanol; [67]), $\mathrm{CH}_{4}$ from strain AmaM methoxydotrophic methanogenesis originated from both the methoxylated substrate $(2 / 3)$ and $\mathrm{CO}_{2}$ (1/3) [6]. We also compared the growth of strain ZC-1 on $\mathrm{TMB}$ and $\mathrm{MeOH}$ and, in agreement, found that the former consumes more $\mathrm{CO}_{2}$ for methanogenesis: in a qualitative experiment with $\left[{ }^{13} \mathrm{C}\right]$ bicarbonate we found that $\mathrm{ZC}-1$ cells grown on TMB produced roughly 10 times more $\left[{ }^{13} \mathrm{C}\right]-\mathrm{CH}_{4}$ from $\left[{ }^{13} \mathrm{C}\right]$-bicarbonate-derived $\mathrm{CO}_{2}$ than those grown on $\mathrm{MeOH}$. Thus, both strains seem to display the same atypical behavior when degrading methoxylated compounds. Given that both strains lack genes for any alternative $C_{1}$ metabolism (e.g., aerobe-like aldehyde-based or anaerobic bacterial $\mathrm{H}_{4}$ F-based metabolism), $\mathrm{H}_{4}$ MPT-dependent $\mathrm{C}_{1}$ metabolism is presumably responsible for running both $\mathrm{CO}_{2}$ and $\mathrm{CH}_{4}$ generation from $\mathrm{ArOCH}_{3}$ as well as $\mathrm{CH}_{4}$ generation from $\mathrm{CO}_{2}$. In search of a metabolic route that provides a rationale for this anomalous behavior and thermodynamic efficiency, we further compare the gene expression of $M$. shengliensis

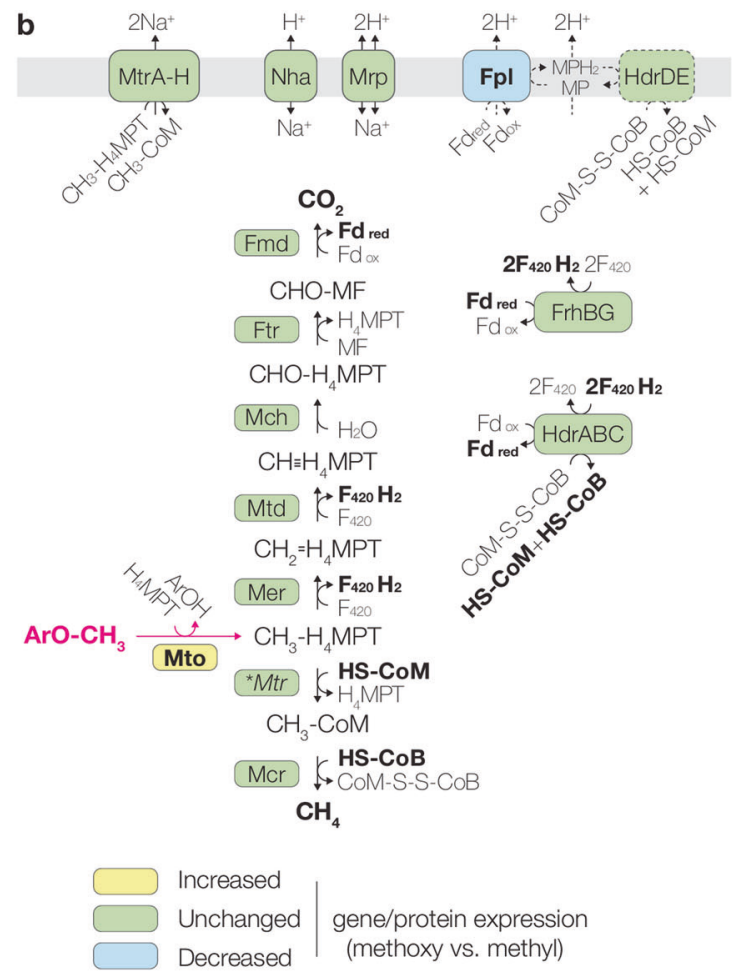

aromatic compounds and methylated compounds. Yellow: genes/proteins for which both strains showed significantly increased expression during methoxydotrophic methanogenesis. Green: genes/proteins for which either (i) expression levels were not significantly different for both strains or (ii) consistent trends were not observed in both strains. Blue: genes/proteins for which both strains showed significantly decreased expression during methoxydotrophic methanogenesis. Arrows involving Fpl and HdrDE are dotted as Fpl was downregulated during methoxydotrophic methanogenesis and, with decreased Fpl activity, HdrDE's activity would consequently decrease as well. $\mathrm{H}_{4}$ MPT tetrahydromethanopterin, MF methanofuran.

when degrading methylated compounds and $\mathrm{ArOCH}_{3}$ to gain insight into how the pathways may differ regarding electron transport and energy recovery.

During methylotrophic growth, AmaM and ZC-1 express the corresponding methyltransferase system and the complete methanogenesis pathway (i.e., $\mathrm{CH}_{3}$-S-CoM disproportionation to $\mathrm{CO}_{2}$ and $\mathrm{CH}_{4}$ ). To transfer electrons from the oxidative to reductive pathway, the two strains express two putative ferredoxin (Fd)-dependent $\mathrm{F}_{420}$ : $\mathrm{CoB}$ S-S-CoM oxidoreductases (HdrA1B1C1 or FrhBGHdrA2B2C2; Eq. 7) [40], a putative Fpo-related Fd: methanophenazine (Mp) oxidoreductase (FplABCDHIJKLMNO; Eq. 8; see Supplementary Table S1) [68, 69], and a Mp-oxidizing membrane-bound heterodisulfide reductase (HdrDE; Eq. 9).

$$
\begin{aligned}
2 \mathrm{~F}_{420} \mathrm{H}_{2}+\mathrm{Fd}_{\mathrm{ox}}+\mathrm{CoM}-\mathrm{S}-\mathrm{S}-\mathrm{CoB} \\
\quad \rightarrow 2 \mathrm{~F}_{420}+\mathrm{Fd}_{\mathrm{red}}+\mathrm{HS}-\mathrm{CoM}+\mathrm{HS}-\mathrm{CoB} \\
\mathrm{Fd}_{\text {red }}+\mathrm{Mp}+4 \mathrm{H}_{\mathrm{in}}^{+} \rightarrow \mathrm{Fd}_{\mathrm{ox}}+\mathrm{MpH}_{2}+2 \mathrm{H}_{\text {out }}^{+}
\end{aligned}
$$




$$
\begin{aligned}
\mathrm{MpH}_{2} & +\mathrm{CoM}-\mathrm{S}-\mathrm{S}-\mathrm{CoB}+2 \mathrm{H}^{+} \\
& \rightarrow \mathrm{Mp}+\mathrm{HS}-\mathrm{CoM}+\mathrm{HS}-\mathrm{CoB}+2 \mathrm{H}_{\text {out }}^{+}
\end{aligned}
$$

Combined together, these complexes can facilitate complete electron transfer for $\mathrm{CH}_{3}-\mathrm{S}-\mathrm{CoM}$ disproportionation (Eq. $7+2$ x Eq. $8+2 x$ Eq. 9; Fig. 5). However, during methoxydotrophic growth, we observe significant decreases in the expression of Fpl compared to methylotrophy (Supplementary Table S1): 3.8-10.1 fold decrease for FplBIMN in AmaM transcriptomes $(p<0.043)$ and 3.2 fold decrease for FplD in ZC-1 proteomes $(p=0.0027)$. Although decreases in all Fpl subunits were not observed, the downregulated subunits play critical roles in the activity of the Fpl complex - FplBI and FplD are predicted to mediate $\mathrm{Fd}_{\text {red }}$ oxidation [68] and interaction with the transmembrane subunits, respectively. Thus, both AmaM and ZC-1 might decrease electron transfer via Fpl and then would have to redirect intracellular electron flow through an alternative pathway. Interestingly, Fpl is central to energy generation from electron transfer (Eqs. 7 and 8), suggesting that $M$. shengliensis switches to an energy acquisition scheme distinct from that of methylotrophic methanogenesis. In other words, while methylotrophic methanogenesis gains energy purely from electron transfer $\left(\mathrm{F}_{420} \mathrm{H}_{2}\right.$ re-oxidation), methoxydotrophic methanogenesis may forgo such energy metabolism and rather gain energy from methyl transfer $\left(\mathrm{CH}_{3}-\mathrm{H}_{4} \mathrm{MPT}\right.$ to $\left.\mathrm{CH}_{3}-\mathrm{S}-\mathrm{CoM}\right)$.

Based on the annotatable genes for methanogenesis and energy metabolism expressed by $M$. shengliensis, the above electron transfer/energy acquisition scheme cannot accomplish complete electron transfer from $\mathrm{CH}_{3}-\mathrm{H}_{4} \mathrm{MPT}$ oxidation to $\mathrm{CH}_{3}-\mathrm{H}_{4} \mathrm{MPT}$ reduction (Fig. S4; see Supplementary Material "Electron transfer metabolism" including Figs. S5 and S6). There is a possibility that $M$. shengliensis possesses genes that encode a novel electron transfer metabolism, but, assuming that this is not the case, $\mathrm{ArOCH}_{3}$ disproportionation would result in accumulation of reducing power distributed among multiple electron carriers (e.g., through activity of a ferredoxin: $\mathrm{F}_{420}$ oxidoreductase and HdrABC). Given that methoxydotrophic methanogenesis was observed to reduce $\mathrm{CO}_{2}$ to $\mathrm{CH}_{4}$, switching to $\mathrm{CO}_{2}$-reducing methanogenesis may allow cells to re-oxidize excess reducing power. Based on a thermokinetic model (see Supplementary Material; Fig. S7), cells could potentially passively alternate between oxidative $\left(\mathrm{ArOCH}_{3}\right.$ disproportionation) and reductive $\left(\mathrm{CO}_{2}\right.$-reducing methanogenesis) metabolism as the cells respectively approach thermodynamic and kinetic limits through accumulation or consumption of cellular reducing power. Although not found in methanogens yet, such repeated intracellularly triggered reversals in metabolism ("metabolic oscillation" or "intracellular feedback loops") involving fluctuation of reducing power (i.e., NADH) have been observed in various organisms, including Klebsiella $s p$. (succinate or glycerol metabolism) [70, 71] and Saccharomyces cerevisiae (glucose) [72]. These oscillations occur on the scale of seconds to hours and concomitantly perform repeated cycles of production and consumption of metabolic end-products (e.g., $\mathrm{CO}_{2}, \mathrm{H}_{2}$, ethanol, or acetate) [71, 73] and intermediates (e.g., ATP) [74]. The proposed theoretical oscillation between oxidative $\mathrm{CO}_{2}-/ \mathrm{CH}_{4}$-liberating $\mathrm{CH}_{3}-\mathrm{H}_{4} \mathrm{MPT}$ disproportionation and $\mathrm{CO}_{2}$-reducing methanogenesis is in line with the predicted need for an alternative electron transfer route (i.e., forgoing energy gain via $\mathrm{Fpl}$ and $\mathrm{Hdr}$ ) and concomitant $\mathrm{CO}_{2}$ generation/consumption during methoxydotrophic methanogenesis, but certainly requires verification.

\section{Conclusion}

In this study, we analysed the growth of the demethoxylating methanogen $M$. shengliensis on methoxylated aromatic compounds and showed that this archaeon uses a demethoxylation system (Mto) similar to those found in acetogenic bacteria. In contrast to the methylotrophic pathway of methanogenic archaea, the methyl group derived from the methoxylated compound is most likely transferred to $\mathrm{H}_{4} \mathrm{MPT}$ instead of CoM. In theory, such activation would thermodynamically require that methoxydotrophic methanogenesis takes an energy acquisition strategy distinct from that of methylotrophic methanogenesis. This hypothesis can be supported by the finding that, during methoxydotrophy, $M$. shengliensis downregulates genes involved in energy-generating electron transfer metabolism that is essential for methylotrophy. Clearly, methoxydotrophic methanogenesis exhibits several interesting features that differ from methylotrophic methanogenesis and requires further investigation to verify the biochemistry of methoxylated aromatic compound activation and downstream energy metabolism.

\section{Data availability}

The mass spectrometry proteomics data have been deposited to the ProteomeXchange Consortium via the PRIDE [75] partner repository with the dataset identifier PXD018934. The transcriptomics data have been deposited under GenBank SRR11935466-SRR11935483.

Acknowledgements JMK was supported by the Deutsche Forschungs Gesellschafts (DFG) Grant KU 3768/1-1. MKN, HT, DM, SS, and YK were supported by Japan Society for the Promotion of Science Grantin-Aid for Scientific Research 18H03367, 18H05295, 17H03800/ 16KK0154/20H00366, 18H02426/26710012, and 17H01363. CUW was supported by the Nederlandse Organisatie voor Wetenschappelijk 
Onderzoek through Grant ALWOP.293. CUW, JMK, and MSMJ were supported by the Nederlandse Organisatie voor Wetenschappelijk Onderzoek through the Soehngen Institute of Anaerobic Microbiology Gravitation Grant 024.002.002 and the Netherlands Earth System Science Center Gravitation Grant 024.002.001. MSMJ was supported by the European Research Council Advanced Grant Ecology of Anaerobic Methane Oxidizing Microbes 339880. NdJ and JLN were supported by a grant from Novo Nordisk Foundation (Grant no. NNF16OC0021818). TW was supported by the Max-PlanckGesellschaft. We thank Theo van Alen, Geert Cremers, Rob de Graaf and Henrik Kjeldal for technical assistance and Huub Op den Camp for helping with MALDI-TOF MS. We also thank Prof. Joseph Krzycki, Ohio State University, for useful discussion on corrinoid protein biochemistry. We thank Ramona Appel and Christina Probian for their technical assistance in the Microbial Metabolism laboratory and the Max Planck Institute for Marine Metabolism for continuous support.

Author contributions MKN, JMK and CUW conceived and designed the study. JMK carried out all experiments performed with $M$. shengliensis ZC-1. JMK and MKN performed omics analyses. JMK, MKN, and CUW interpreted the omics data. TW and JMK designed and conducted the protein purification and biochemical characterization. MKN performed metabolic/thermodynamic reconstruction. NdJ performed initial proteomics analysis with guidance of JLN. SB did the initial culturing of $M$. shengliensis ZC-1. JMK and MKN took lead in writing the manuscript. JMK, MKN, and CUW integrated feedback from all authors into the manuscript. KY and JLN supported experimental work. DM, HT, SS, YK, MSMJ provided critical feedback. All authors discussed the results and commented on the manuscript.

\section{Compliance with ethical standards}

Conflict of interest The authors declare no competing interests.

Publisher's note Springer Nature remains neutral with regard to jurisdictional claims in published maps and institutional affiliations.

Open Access This article is licensed under a Creative Commons Attribution 4.0 International License, which permits use, sharing, adaptation, distribution and reproduction in any medium or format, as long as you give appropriate credit to the original author(s) and the source, provide a link to the Creative Commons license, and indicate if changes were made. The images or other third party material in this article are included in the article's Creative Commons license, unless indicated otherwise in a credit line to the material. If material is not included in the article's Creative Commons license and your intended use is not permitted by statutory regulation or exceeds the permitted use, you will need to obtain permission directly from the copyright holder. To view a copy of this license, visit http://creativecommons. org/licenses/by/4.0/.

\section{References}

1. Ueno Y, Yamada K, Yoshida N, Maruyama S, Isozaki Y. Evidence from fluid inclusions for microbial methanogenesis in the early Archaean era. Nature. 2006;440:516-9.

2. Thauer RK, Kaster A-K, Seedorf H, Buckel W, Hedderich R. Methanogenic archaea: ecologically relevant differences in energy conservation. Nat Rev Microbiol. 2008;6:579-91.

3. Conrad R. The global methane cycle: recent advances in understanding the microbial processes involved. Environ Microbiol Rep. 2009;1:285-92.
4. Deppenmeier U, Mueller V, Gottschalk G. Pathways of energy conservation in methanogenic archaea. Arch Microbiol. 1996;165:149-63.

5. Cheng L, Qiu TL, Yin XB, Wu XL, Hu GQ, Deng Y, et al. Methermicoccus shengliensis gen. nov., sp. nov., a thermophilic, methylotrophc methanogen isolated from oil-production water, and proposal of Methermicoccaceae fam. nov. Int J Syst Evol Microbiol. 2007;57:2964-9.

6. Mayumi D, Mochimaru H, Tamaki H, Yamamoto K, Yoshioka H, Suzuki Y, et al. Methane production from coal by a single methanogen. Science. 2016;354:222-5.

7. De Leeuw JW, Largeau C. A review of macromolecular organic compounds that comprise living organisms and their role in kerogen, coal, and petroleum formation. Organic Geochem. 1993;11:23-72.

8. Welte CU. A microbial route from coal to gas. Science. 2016;354:184-184.

9. Libes SM. The origin of petroleum in the marine environment. Introduction to marine biogeochemistry. Cynar F, Bugeau P, Kelleher L, Versteeg L. editors. Ch. 26. Amsterdam: Elsevier Science, 2009. pp 1-33.

10. Meslé M, Dromart G, Oger P. Microbial methanogenesis in subsurface oil and coal. Res Microbiol. 2013;164:959-72.

11. Gruendger F, Jiménez N, Thielemann T, Straaten N, Lueders T, Richnow $\mathrm{H}-\mathrm{H}$, et al. Microbial methane formation in deep aquifers of a coal-bearing sedimentary basin, Germany. Front Microbiol. 2015;6:1-17.

12. Krüger M, Beckmann S, Engelen B, Thielemann T, Cramer B, Schippers A, et al. Microbial methane formation from hard coal and timber in an abandoned coal mine. Geomicrobiol J. 2008;25:315-21.

13. Ritter D, Vinson D, Barnhart E, Akob DM, Fields MW, Cunningham $\mathrm{AB}$, et al. Enhanced microbial coalbed methane generation: a review of research, commercial activity, and remaining challenges. Int J Coal Geol. 2015;146:28-41.

14. Ferguson DJ, Krzycki JA, Grahame DA. Specific roles of methylcobamide:coenzyme $M$ methyltransferase isozymes in metabolism of methanol and methylamines in Methanosarcina barkeri. J Biol Chem. 1996;271:5189-94.

15. Boutet E, Lieberherr D, Tognolli M, Schneider M, Bairoch A. UniProtKB/Swiss-Prot: the manually annotated section of the UniProt KnowledgeBase. Methods Mol Biol. 2007;406:89-112.

16. Katoh K, Standley DM. MAFFT multiple sequence alignment software version 7: Improvements in performance and usability. Mol Biol Evol. 2013;30:772-80.

17. Kozlov AM, Darriba D, Flouri T, Morel B, Stamatakis A. RAxMLNG: a fast, scalable and user-friendly tool for maximum likelihood phylogenetic inference. Bioinformatics. 2019;35:4453-5.

18. Price MN, Dehal PS, Arkin AP. FastTree 2 - Approximately maximum-likelihood trees for large alignments. PLoS ONE. 2010;5:1-10.

19. Jones P, Binns D, Chang HY, Fraser M, Li W, McAnulla C, et al. InterProScan 5: genome-scale protein function classification. Bioinformatics. 2014;30:1236-40.

20. Petersen TN, Brunak S, Von Heijne G, Nielsen H. SignalP 4.0: discriminating signal peptides from transmembrane regions. Nat Methods. 2011;8:785-6.

21. Sekiguchi Y, Kamagata Y, Nakamura K, Ohashi A, Harada H. Syntrophothermus lipocalidus gen. nov., sp. nov., a novel thermophilic, syntrophic, fatty-acid-oxidizing anaerobe which utilizes isobutyrate. Int J Syst Evol Microbiol. 2000;50:771-9.

22. Takai K, Horikoshi K, Takai KEN. Rapid detection and quantification of members of the archaeal community by quantitative PCR using fluorogenic probes rapid detection and quantification of members of the archaeal community by quantitative PCR using fluorogenic probes. Appl Environ Microbiol. 2000;66:5066-72. 
23. Schmidt TM, DeLong EF, Pace NR. Analysis of a marine picoplankton community by $16 \mathrm{~S}$ rRNA gene cloning and sequencing. J Bacteriol. 1991;173:4371-8.

24. Bolger AM, Lohse M, Usadel B. Trimmomatic: a flexible trimmer for Illumina sequence data. Bioinformatics. 2014;30:2114-20.

25. Yu Y, Smith M, Pieper R. A spinnable and automatable StageTip for high throughput peptide desalting and proteomics. Protoc Exch. 2014; https://doi.org/10.1038/protex.2014.033.

26. Tyanova S, Temu T, Cox J. The MaxQuant computational platform for mass spectrometry-based shotgun proteomics. Nat Protoc. 2016;11:2301-19.

27. Tyanova S, Temu T, Sinitcyn P, Carlson A, Hein MY, Geiger T, et al. The Perseus computational platform for comprehensive analysis of (prote)omics data. Nat Methods. 2016;13:731-40.

28. Schilhabel A, Studenik S, Voedischo M, Kreher S, Schlott B, Pierik AY, et al. The ether-cleaving methyltransferase system of the strict anaerobe Acetobacterium dehalogenans: analysis and expression of the encoding genes. J Bacteriol. 2009;191:588-99.

29. Siebert A, Schubert T, Engelmann T, Studenik S, Diekert G. Veratrol-O-demethylase of Acetobacterium dehalogenans: ATPdependent reduction of the corrinoid protein. Arch Microbiol. 2005;183:378-84.

30. Preiner M, Igarashi K, Muchowska KB, Yu M, Varma SJ, Kleinermanns $\mathrm{K}$, et al. A hydrogen-dependent geochemical analogue of primordial carbon and energy metabolism. Nat Ecol Evol. 2020;4:534-42.

31. Joback KG, Reid RC. Estimation of pure-component properties from group-contributions. Chem Eng Commun. 1987;57:233-43.

32. Bertram PA, Karrasch M, Schmitz RA, Boecher R, Albracht SPJ, Thauer RK. Formylmethanofuran dehydrogenases from methanogenic archaea. Substrate specificity, EPR properties and reversible inactivation by cyanide of the molybdenum or tungsten ironsulfur proteins. Eur J Biochem. 1994;220:477-84.

33. Thauer RK. Energy metabolism of methanogenic bacteria. Biochim Biophys Acta. 1990;1018:256-9.

34. Donnelly MI, Escalante-Semerena JC, Rinehart K, Wolfe R. Methenyl-tetrahydromethanopterin cyclohydrolase in cell extracts of Methanobacterium. Arch Biochem Biophys. 1995;242:430-9.

35. Escalante-Semerena JC, Rinehart KL, Wolfe RS. Tetrahydromethanopterin, a carbon carrier in methanogenesis. J Biol Chem. 1984;259:9447-55.

36. Daniels L. Biochemistry of methanogenesis. New comprehensive biochemistry. Kates M, Kushner DJ, Matheson AT. editors. Amsterdam: Elsevier: 1993. pp 41-112.

37. Gärtner P, Weiss DS, Harms U, Thauer RK. N5-methyltetrahydromethanopterin:coenzyme M methyltransferase from Methanobacterium thermoautotrophicum. Catalytic mechanism andsodium ion dependence. Eur J Biochem. 1994;226:465-72.

38. de Poorter LMI, Geerts WJ, Keltjens JT. Hydrogen concentrations in methane-forming cells probed by the ratios of reduced and oxidized coenzyme F420. Microbiology. 2005;151:1697-705.

39. Keltjens JT, van der Drift C. Electron transfer reactions in methanogens. FEMS Microbiol Rev. 1986;39:259-303.

40. Yan Z, Wang M, Ferry JG. A ferredoxin- and F420H2-dependent, electron-bifurcating, heterodisulfide reductase with homologs in the domains bacteria and archaea. MBio. 2017;8:1-15.

41. Tietze M, Beuchle A, Lamla I, Orth N, Dehler M, Greiner G, et al. Redox potentials of methanophenazine and CoB-S-S-CoM, factors involved in electron transport in methanogenic archaea. ChemBioChem. 2003;4:333-5.

42. González-Cabaleiro R, Lema JM, Rodriguez J, Kleerebezem R. Linking thermodynamics and kinetics to assess pathway reversibility in anaerobic bioprocesses. Energy Environ Sci. 2013;6:3780-9.

43. Sauer K, Harms U, Thauer RK. Methanol:Coenzyme M methyltransferase from Methanosarcina barkeri purification, properties and encoding genes of the corrinoid protein MT1. Eur J Biochem. 1997;243:670-7.

44. Kaufmann F, Wohlfarth G, Diekert G. Isolation of O-demethylase, an ether-cleaving enzyme system of the homoacetogenic strain MC. Arch Microbiol. 1997;168:136-42.

45. Oelgeschläger E, Rother M. Influence of carbon monoxide on metabolite formation in Methanosarcina acetivorans. FEMS Microbiol Lett. 2009;292:254-60.

46. Naidu D, Ragsdale SW. Characterization of a three-component vanillate O-demethylase from Moorella thermoacetica. J Bacteriol. 2001;183:3276-81.

47. Sharak Genthner BR, Bryant MP. Additional characteristics of one-carbon-compound utilization by Eubacterium limosum and Acetobacterium woodii. Appl Environ Microbiol. 1987;53:471-6.

48. Kane MD, Breznak JA. Acetonema longum gen. nov. sp. nov., an $\mathrm{H} 2 / \mathrm{CO} 2$ acetogenic bacterium from the termite, Pterotermes occidentis. Arch Microbiol. 1991;156:91-8.

49. Hattori S, Kamagata Y, Hanada S, Shoun H. Thermacetogenium phaeum gen. nov., sp. nov., a strictly anaerobic, thermophilic, syntrophic acetate-oxidizing bacterium. Int J Syst Evol Microbiol. 2000;50:1601-9.

50. Kuesel K, Dorsch T, Acker G, Stackebrandt E, Drake HL. Clostridium scatologenes strain SL1 isolated as an acetogenic bacterium from acidic sediments. Int $\mathrm{J}$ Syst Evol Microbiol. 2000;50:537-46.

51. Studenik S, Vogel M, Diekert G. Characterization of an ODemethylase of Desulfitobacterium hafniense DCB-2. J Bacteriol. 2012;194:3317-26.

52. Saier MH, Beatty JT, Goffeau A, Harley KT, Heijne WHM, Huang S, et al. The major facilitator superfamily. J Mol Microbiol Biotechnol. 1999;1:257-79.

53. Nichols NN, Harwood CS. PcaK, a high-affinity permease for the aromatic compounds 4-hydroxybenzoate and protocatechuate from Pseudomonas putida. J Bacteriol. 1997;179:5056-61.

54. Leveau JHJ, Zehnder AJB, van der Meer JR. The tfdK gene product facilitates uptake of 2,4-dichlorophenoxyacetate by Ralstonia eutropha JMP134(pJP4). J Bacteriol. 1998;180:2237-43.

55. Collier LS, Nichols NN, Neidle EL. benK encodes a hydrophobic permease-like protein involved in benzoate degradation by Acinetobacter sp. Strain ADP1. J Bacteriol. 1997;179:5943-6.

56. Williams PA, Shaw LE. mucK, a gene in Acinetobacter calcoaceticus ADP1 (BD413), encodes the ability to grow onexogenous cis,cis-muconate as the sole carbon source. J Bacteriol. 1997; 179:5935-42.

57. D'Argenio DA, Segura ANA, Coco WM, Buenz PV, Ornston LN. The physiological contribution of Acinetobacter PcaK, a transport system that acts upon protocatechuate, can be masked by the overlapping specificity of VanK. J Bacteriol. 1999;181:3505-15.

58. Xu Y, Chen B, Chao H, Zhou N. mhpT encodes an active transporter involved in 3-(3-hydroxyphenyl)propionate catabolism by Escherichia coli K-12. Appl Environ Microbiol. 2013;79:6362-8.

59. Sauer K, Thauer RK. Chemistry and Biochemistry of B12. In: Banerjee R (ed.). Chemistry and biochemistry of B12. Canada: John Wiley \& Sons, 1999. pp 655-680.

60. Pierce E, Xie G, Barabote RD, Saunders E, Han CS, Detter JC, et al. The complete genome sequence of Moorella thermoacetica (f. Clostridium thermoaceticum). Environ Microbiol. 2008;10:2550-73.

61. Wang S, Chen Y, Cao Q, Lou H. Long-lasting gene conversion shapes the convergent evolution of the critical methanogenesis genes. G3. 2015;5:2475-86.

62. Ticak T, Kountz DJ, Girosky KE, Krzycki JA, Ferguson DJ. A nonpyrrolysine member of the widely distributed trimethylamine methyltransferase family is a glycine betaine methyltransferase. Proc Natl Acad Sci USA. 2014;111:E4668-76.

63. Ferry JG. Methane from acetate. J Bacteriol. 1992;174:5489-95. 
64. Thauer RK, Jungermann K, Decker K. Energy conservation in chemotrophic anaerobic bacteria. Bacteriol Rev. 1977;41:100-80.

65. Flamholz A, Noor E, Bar-Even A, Liebermeister W, Milo R. Glycolytic strategy as a tradeoff between energy yield and protein cost. Proc Natl Acad Sci USA. 2013;110:10039-44.

66. Stettner AI, Segrè D. The cost of efficiency in energy metabolism. Proc Natl Acad Sci USA. 2013;110:9629-30.

67. Stadtman TC, Barker HA. Studies on the methane fermentation. IX. The origin of methane in the acetate and methanol fermentations by Methanosarcina. J Bacteriol. 1951;61:81-6.

68. Welte C, Deppenmeier U. Membrane-bound electron transport in Methanosaeta thermophila. J Bacteriol. 2011;193:2868-70.

69. Schut GJ, Zadvornyy O, Wu C-H, Peters JW, Boyd ES, Adams MWW. The role of geochemistry and energetics in the evolution of modern respiratory complexes from a proton-reducing ancestor. BBA - Bioenerg. 2016;1857:958-70.

70. Harrison DEF, Topiwala HH. Transient and oscillatory states of continuous culture. Adv Biochem Eng. 1974;3:167-219.
71. Menzel K, Ahrens K, Zeng A-P, Deckwer W-D. Kinetic, dynamic, and pathway studies of glycerol metabolism by Klebsiella pneumoniae in anaerobic continuous culture: I. The phenomena and characterization of oscillation and hysteresis. Biotechnol Bioeng. 1996;52:549-60.

72. Dodd BJT, Kralj JM. Live cell imaging reveals $\mathrm{pH}$ oscillations in Saccharomyces cerevisiae during metabolic transitions. Sci Rep. 2017;7:1-12.

73. Lee KJ, Tribe DE, Rogers PL. Ethanol production by Zymomonas mobilis in continuous culture at high glucose concentrations. Biotechnol Lett. 1979;1:421-6.

74. Termonia Y, Ross J. Oscillations and control features in glycolysis: analysis of resonance effects. Proc Natl Acad Sci USA. 1981;78:2952-6.

75. Perez-Riverol Y, Csordas A, Bai J, Bernal-Llinares M, Hewapathirana S, Kundu DJ, et al. The PRIDE database and related tools and resources in 2019: improving support for quantification data. Nucleic Acids Res. 2019;47:D442-50. 